INTERNATIONAL FOOD

POLICY RESEARCH INSTITUTE

sustainable solutions for ending hunger and poverty

Supported by the CGIAR

IFPRI Discussion Paper 00947

January 2010

\title{
Agricultural Growth, Poverty, and Nutrition in Tanzania
}

\author{
Karl Pauw
}

James Thurlow

Development Strategy and Governance Division 


\section{INTERNATIONAL FOOD POLICY RESEARCH INSTITUTE}

The International Food Policy Research Institute (IFPRI) was established in 1975. IFPRI is one of 15 agricultural research centers that receive principal funding from governments, private foundations, and international and regional organizations, most of which are members of the Consultative Group on International Agricultural Research (CGIAR).

\section{FINANCIAL CONTRIBUTORS AND PARTNERS}

IFPRI's research, capacity strengthening, and communications work is made possible by its financial contributors and partners. IFPRI receives its principal funding from governments, private foundations, and international and regional organizations, most of which are members of the Consultative Group on International Agricultural Research (CGIAR). IFPRI gratefully acknowledges the generous unrestricted funding from Australia, Canada, China, Finland, France, Germany, India, Ireland, Italy, Japan, Netherlands, Norway, South Africa, Sweden, Switzerland, United Kingdom, United States, and World Bank.

\section{AUTHORS}

Karl Pauw, International Food Policy Research Institute

Postdoctoral Fellow, Development Strategy and Governance Division k.pauw@cgiar.org

James Thurlow, International Food Policy Research Institute

Research Fellow, Development Strategy and Governance Division j.thurlow@cgiar.org

\footnotetext{
Notices

${ }^{1}$ Effective January 2007, the Discussion Paper series within each division and the Director General's Office of IFPRI were merged into one IFPRI-wide Discussion Paper series. The new series begins with number 00689, reflecting the prior publication of 688 discussion papers within the dispersed series. The earlier series are available on IFPRI's website at http://www.ifpri.org/category/publication-type/discussion-papers.

2 IFPRI Discussion Papers contain preliminary material and research results. They have not been subject to formal external reviews managed by IFPRl's Publications Review Committee but have been reviewed by at least one internal and/or external reviewer. They are circulated in order to stimulate discussion and critical comment.
} 


\section{Contents}

Abstract $\quad$ V

1. Introduction 1

2. Agriculture, Poverty, and Nutrition in Tanzania 2

3. Poverty Reduction under Tanzania’s Current Growth Path 7

4. Accelerating Broad-Based Agricultural Growth 12

5. Comparing Alternative Sources of Agricultural Growth 17

6. Conclusions and Policy Implications 20

Appendix A: Specification of the DCGE Model 21

Appendix B: Measuring Poverty and Nutrition Outcomes 26

Appendix C: Comparing Alternative Poverty-Growth Elasticities in Tanzania 28

$\begin{array}{ll}\text { References } & 30\end{array}$ 


\section{List of Tables}

1. Agricultural production statistics 2

2. Calories per serving, price per kilocalorie, and urban-rural calorie composition 5

3. Crop yields and area and production outcomes under the baseline and agriculture scenarios (national level)

4. GDP growth rates in the baseline and agriculture scenarios 9

5. Changes in poverty headcount and calorie deficiency rates in the model 15

6. Poverty-growth and calorie-growth elasticities under alternative growth scenarios 17

7. Economywide growth-linkage effect of agriculture under the agriculture scenario 18

A.1. Simple CGE model equations $\quad 21$

A.2. Sectors and regions in the Tanzania DCGE model 24

A.3. Land and population distribution across regions and farm households 25

B.1. Caloric equivalence scales (measured relative to adult males, aged 19 to 59) 26

C.1. Alternative estimates of poverty-growth elasticities 28

\section{List of Figures}

1. Nonparametric estimates of income-calorie curves (Lowess smoothing) 4

2. National poverty rate under alternative agricultural growth scenarios 10

3. Relative producer price changes under the agriculture scenario 13

4. Prioritizing agricultural sectors for investment 19

A.1. Regions and zones in the Tanzania DCGE model 23 


\begin{abstract}
Rapid economic growth has failed to significantly improve poverty and nutrition outcomes in Tanzania. This raises concerns over a decoupling of growth, poverty, and nutrition. We link recent production trends to household incomes using a regionalized, dynamic computable general equilibrium and microsimulation model. Results indicate that the structure of economic growth — not the level — is currently constraining the rate of poverty reduction in Tanzania. Most importantly, agricultural growth trends have been driven by larger-scale farmers and by crops grown in only a few regions of the country. The slow expansion of food crops and livestock also explains the weak relationship between agricultural growth and nutrition outcomes. Additional model simulations find that accelerating agricultural growth, particularly in maize, greatly strengthens the growth-poverty relationship and enhances households' caloric availability. We conclude that low productivity, market constraints (including downstream agroprocessing), and barriers to import substitution for major food crops are among the more binding constraints to reducing poverty and improving nutrition in Tanzania.
\end{abstract}

Keywords: economic growth, poverty, nutrition, computable general equilibrium modeling, Tanzania 



\section{INTRODUCTION}

Despite its poor performance during the 1990s, the economy of Tanzania expanded rapidly after the turn of the century, with national gross domestic product (GDP) growing at 6.6 percent per year during 19982007 (MOFEA 2008). Economic growth also appears to have been relatively broad based. Although the newly established gold-mining sector recorded the highest growth rates during 1998-2007, the large agriculture and manufacturing sectors contributed the most to national growth. However, despite Tanzania's high and seemingly broad-based economic growth, household income poverty has remained virtually unchanged. The national poverty headcount fell only 2.1 percentage points, from 35.7 percent in 2000-2001 to 33.6 percent in 2007, with equally modest declines in rural and urban areas (World Bank 2009). Economic growth therefore appears to have little effect on poverty in Tanzania. Indeed, the country's poverty-growth elasticity was at most 0.76 during $2001-2007 .^{1}$ This relatively weak relationship raises concerns over a possible decoupling of economic growth and poverty reduction in Tanzania. Moreover, the household surveys find that income inequality did not change significantly during 2001-2007 (World Bank 2009). This suggests an inconsistency between the high growth reported in national accounts and the small changes in poverty and inequality from the household surveys. Together, the weak poverty-growth elasticity and the inconsistency between growth, poverty, and inequality trends underline the need to better understand the consequences of alternative sources of growth.

Along with persistent income poverty, Tanzania also suffers from high levels of malnutrition. About 17 percent of children are underweight, and 4 out of every 10 children are stunted (World Bank 2007, 2008). Recent trends suggest that while average per capita agricultural GDP expanded rapidly during 1998-2007, caloric availability at the household level hardly improved. For example, estimates based on the two latest household surveys show that the share of people who had insufficient calories available to them fell only slightly, from around 25.0 to 23.5 percent, between 2000-2001 and 2007 (World Bank 2009). This suggests that rising farm and national incomes have little effect on households' access to food, ability to acquire food, or both; and it raises further concerns about a possible disconnect between agricultural growth and nutritional outcomes.

Tanzania's development outcomes over the last decade raise three questions. First, is the level and structure of the current economic growth path consistent with the slow decline in national poverty and only modest improvement in caloric availability? Second, what is the contribution of agriculture in reducing poverty and raising caloric availability? Finally, which agricultural subsectors are most effective at achieving national growth, poverty, and nutrition objectives? We address these questions using a regionalized and dynamic computable general equilibrium (DCGE) model. A microsimulation module is linked sequentially to the DCGE model to measure how changes in economic growth affect households in terms of poverty and food expenditure levels, which in turn determines caloric availability. ${ }^{2}$ Section 2 reviews recent agricultural production trends in Tanzania and examines the relationship between poverty and nutrition. Section 3 uses the DCGE model to estimate the poverty impacts of Tanzania's current growth path, thereby assessing the consistency between recent growth and poverty trends. Section 4 then estimates the impact of accelerating broad-based agricultural growth as a means of strengthening the growth-poverty relationship. Based on these findings, Section 5 identifies agricultural subsectors that are most effective at generating economic growth, reducing income poverty, and improving caloric availability in households. The final section summarizes our findings and their policy implications.

\footnotetext{
${ }^{1}$ Appendix $\mathrm{C}$ discusses the discrepancies between growth and poverty estimates in Tanzania and the difficulties in measuring poverty-growth elasticities.

${ }^{2}$ Appendixes A and B describe the DCGE model and microsimulation module, respectively.
} 


\section{AGRICULTURE, POVERTY, AND NUTRITION IN TANZANIA}

In this section we examine the structure and recent performance of the agricultural sector and use microsurvey data to explore the relationship between household consumption and caloric availability. This provides the context for the forward-looking assessments in subsequent sections.

\section{Recent Agricultural Production Trends}

Table 1 shows the structure of crop production in Tanzania. More than half of the total harvested land area is allocated to cereals, of which maize is the country's dominant staple food crop. Despite its favorable agroecological conditions, Tanzania is a net importer of cereals. Maize yields are typically low ( 0.88 tons per hectare) because smallholder farmers rely on traditional technologies and produce mainly for subsistence (MINAG 2004). Wheat, on the other hand, is produced almost exclusively by large-scale commercial farmers in the Northern zone using modern inputs. Growth in cereals production varies greatly by crop (FAO 2009). Maize production expanded more slowly than the overall population during 2000-2007, implying declining per capita production. In contrast, wheat and rice grew rapidly over the same period, with rice becoming a particularly important crop for smallholder farmers in the Western and Lake zones (MINAG 2006) and an important food source for higher-income households (World Bank 2009). Indeed, even the rapid expansion of rice and wheat production has failed to keep pace with rising consumer demand, causing imports to rise. Thus, it was rice and wheat that drove cereals production growth during 2000-2007, and not more widely produced maize.

Table 1. Agricultural production statistics

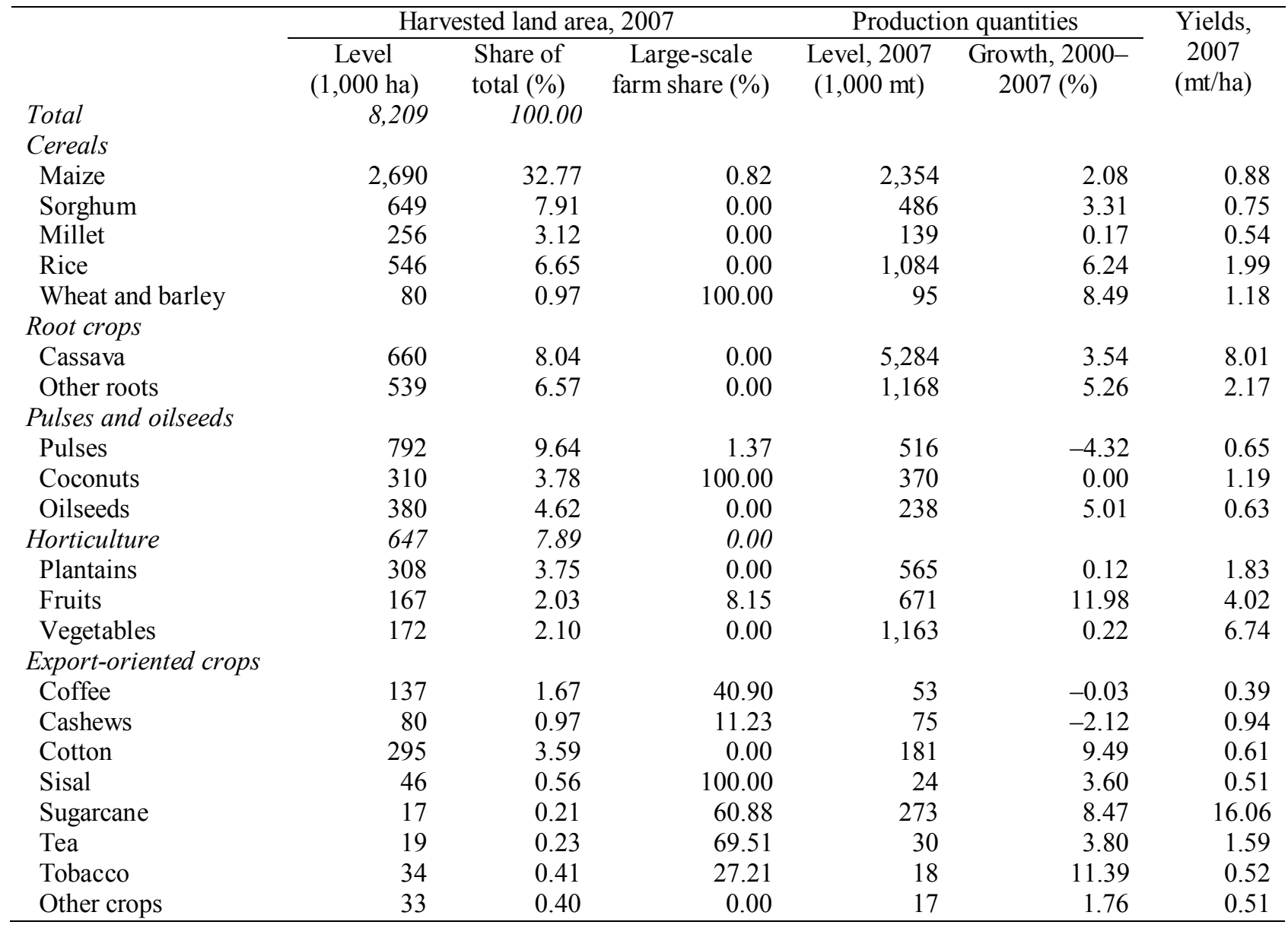

Source: Authors' calculations using Tanzania DCGE and microsimulation model, FAOSTAT (FAO 2009), and the 2002-2003 Agricultural Sample Survey (MINAG 2004). 
Roots, such as cassava and potatoes, are also important food sources in Tanzania and account for almost 15 percent of harvested land. Root crops performed well during 2000-2007, with more than 4 percent annual growth. In contrast, higher-value pulses and vegetables stagnated, with pulses production declining by more than 4 percent each year. This was offset by rapid growth of fruit production in the Northern and Eastern zones, and by oilseed crops grown in most parts of the country. Noncereal food crop production has therefore been characterized by slow growth in the more widely produced pulses and vegetables crops and by fast growth in more regionally concentrated fruits.

Some of the fastest growth rates during 2000-2007 were for export-oriented crops. Traditional crops, such as cotton, sugarcane, and tobacco, grew at almost 10 percent per year. These crops are highly concentrated in specific regions. Cotton is mostly produced by smallholders in the Western and Lake zones (81.5 percent of output). Tobacco, another smallholder crop, is mainly produced in the Western and Highlands zones ( 82.8 percent). Finally, sugarcane is mostly produced by larger-scale commercial farmers in the Eastern and Northern zones ( 83.8 percent). Together these three crops generated 17.4 percent of the total export merchandise in 2007. Coffee and tobacco are also major export crops, but their production has declined in recent years. Export agriculture therefore grew rapidly during 2000-2007, driven by the strong performance of a few regionally concentrated crops.

Finally, livestock and fisheries are key subsectors, accounting for almost a third of agricultural GDP. Fisheries kept pace with overall agricultural production during 1998-2007, growing at 5.1 percent per year. However, livestock has lagged behind crop agriculture, growing at only 3.3 percent per year. Incomes from cattle and poultry are important for farm livelihoods in many parts of the country, and especially for lower-income households (World Bank 2009). Thus, their slow growth will have implications for household incomes, especially for the poor.

An examination of recent production trends suggest that although the agricultural sector as a whole grew rapidly during 2000-2007, the source of this growth has been concentrated among a few crops. Rice and wheat, for example, dominate cereals production trends; cotton, tobacco, and sugar grew at almost 10 percent per year. These well-performing crops are more heavily concentrated in the northern and eastern periphery of the country and are more often produced by larger-scale commercial farmers. Thus, while the strong expansion of the aggregate agricultural sector in recent years suggests that economic growth in Tanzania is broad based, a closer examination of agricultural production data suggests the opposite. In Section 3 we use the DCGE to replicate these production trends and consider their implications for poverty reduction and changes in caloric availability.

\section{Economic Growth and Household Nutrition}

Household nutrition status has not improved substantially, despite high rates of economic growth. For instance, based on a calorie line of 2,550 kilocalories per adult equivalent per day, the share of the population with insufficient calorie consumption declined only marginally from approximately 25.0 to 23.5 percent during 2001-2007 (World Bank 2009). ${ }^{3}$ Similarly, while the share of underweight children fell from 25 percent to 17 percent during 1999-2005, the rate of child stunting remained virtually unchanged at about 40 percent of children under the age of five (Alderman et al. 2006; World Bank 2007, 2008). As with poverty, these poor outcomes raise concerns over why rapid economic growth has not translated into much greater improvements in nutritional outcomes.

The analysis here focuses only on the availability of calories at the household level, drawing on household expenditure survey information on purchased foods. The use of household-level expenditure survey data necessitates the use of the term caloric availability as opposed to caloric intake, because the

\footnotetext{
${ }^{3}$ Tanzania's "official" calorie line is 2,200 kilocalories and was used by the National Bureau of Statistics in the estimation of a food poverty line for the country (NBS 2002). The World Bank (2009) used 2,550 kilocalories as a benchmark, which is a "general" calorie line recommended by the UNU, WHO, and FAO (2004) for male adults involved in "light activity". This line is higher than the calorie lines typically used in African studies, but in order to ensure comparability with the World Bank (2009) results, we use this same calorie line in the analyses here (also see Appendix B).
} 
quantities of food actually consumed by household members themselves and the distribution of purchased foods among its members cannot be determined. ${ }^{4}$

Caloric availability is only one dimension of nutrition. For example, a joint report by the United Nations University (UNU), World Health Organization (WHO), and Food and Agriculture Organization of the United Nations (FAO) warns that energy needs should ideally not be considered in isolation of other nutrients in the diet (particularly micronutrients such as minerals and vitamins), because "the lack of one will influence the others" (UNU, WHO, and FAO 2004:4). However, in reality, poor households typically allocate large shares of their budgets to food types with high caloric content, mainly to avoid feelings of hunger (Ecker and Qaim 2009). From that perspective, and given our joint focus on poverty, this study's focus on caloric availability is justifiable.

It is generally accepted that the relationship between per capita incomes and caloric availability is positive. The relationship is further characterized by a calorie-income elasticity that is inelastic, meaning that a 1 percent increase in income (measured at the mean) is associated with a less than 1 percent increase in calories, causality issues aside. The surveys by Strauss and Thomas (1995) and Hoddinott et al. (2000) suggest that elasticities estimated from calorie demand equations in developing countries fall mostly between 0.3 and 0.5 , although some studies have estimated values as low as 0.11 . For Tanzania, Abdulai and Aubert (2004) estimate an elasticity of between 0.49 and 0.53 .

While parametric analyses are useful for obtaining point estimates of calorie-income elasticities, nonparametric analyses often suggest strong nonlinearities in this relationship, with households at the lower end of the income distribution typically displaying higher calorie-income elasticities than wealthier households (see Strauss and Thomas 1995; Subramanian and Deaton 1996; and Hoddinott et al. 2000). The same is true for Tanzania, where, according to the Household Budget Survey (HBS) 2000-2001 (NBS 2002), the calorie-income curve becomes noticeably flatter at or beyond the median per capita income level and above the minimum daily caloric requirement (Figure 1).

\section{Figure 1. Nonparametric estimates of income-calorie curves (Lowess smoothing)}

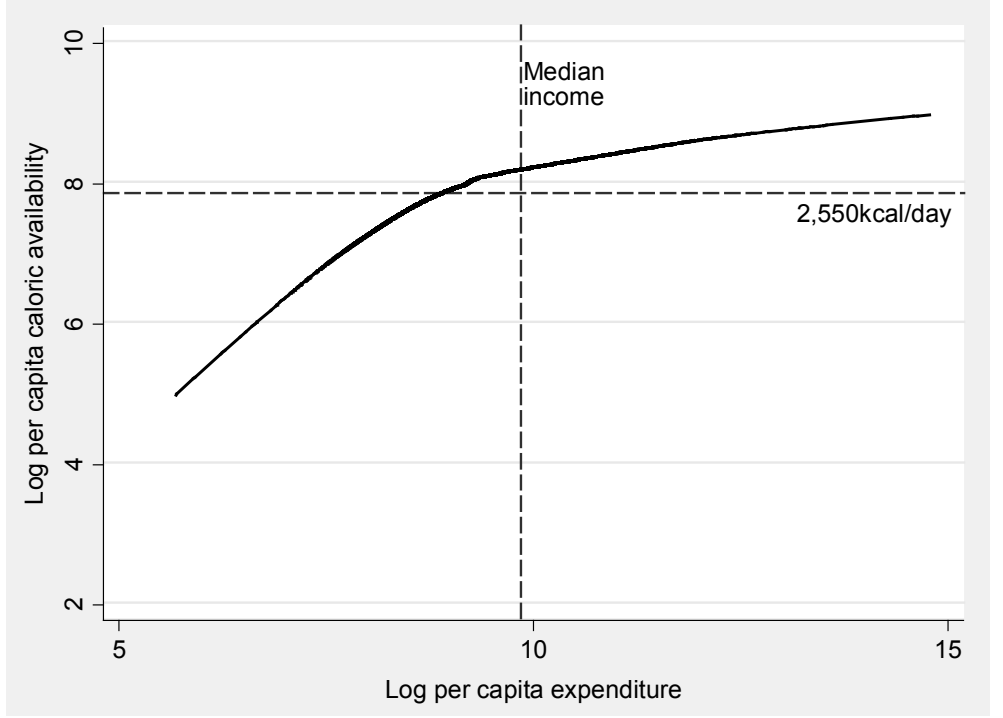

Source: Authors' estimates using the HBS 2000-2001 (NBS 2002).

The aim of this study is to improve our understanding of the relationship between economic growth and improvements in caloric availability over time. We use a calorie-growth analysis, which is more nuanced than but related to a calorie-income relationship, where real per capita GDP growth

\footnotetext{
${ }^{4}$ Appendix B elaborates on the "nutrition module" and the methods used to extract information on caloric availability from the household survey data.
} 
implies higher household incomes and hence an increased availability of calories in the average household.

In order to ensure comparability with poverty-growth elasticities also used in this analysis (see Appendix C), we define the calorie-growth elasticity as the percentage change in the calorie deficiency rate divided by the percentage change in per capita GDP. ${ }^{5}$ The calorie deficiency rate is similar to a poverty headcount rate in that it indicates the share of the population that is below the calorie line. According to national accounts, per capita GDP grew at 3.99 percent per year during 2001-2007, while the household surveys estimate that the calorie deficiency rate fell by 1.03 percent per year (i.e., from 25.0 to 23.5 percent). This gives a calorie-growth elasticity of 0.26 (i.e., $1.03 / 3.99){ }^{6}$ In contrast to the normal calorie-income elasticity, which considers changes in average caloric availability, the caloriegrowth elasticity is sensitive to growth-induced changes in caloric availability in households close to the calorie deficiency line only.

The DCGE model incorporates a very detailed set of food commodity accounts. Each of these food types is associated with a certain calorie content. Column 2 of Table 2 shows how the price per 100 kilocalories varies across food products. For example, livestock products have larger calorie contents per serving than other animal products and most other foods. However, the higher price of animal products means that these are ultimately an expensive source of energy. The final two columns show that a large share of daily calories available to food-insecure households is obtained from foods with low prices per calorie.

The nature of economic growth will clearly be important in determining the nutrition impact. First, with regard to the distribution of growth, it is clear that if growth favors high-income households, the average availability of calories may not rise as much as under a pro-poor growth scenario given the lower calorie-income elasticities in high-income households. Second, different compositions of economic growth may have differential impacts on relative food prices. Whether policies cause reductions in root crop prices or cereal prices may have very different implications for caloric availability given caloric contents of these foods. Furthermore, given differences in food expenditure patterns across different household types, one growth strategy may be good for poverty reduction, while another may be favored for its nutrition impacts.

Table 2. Calories per serving, price per kilocalorie, and urban-rural calorie composition

\begin{tabular}{|c|c|c|c|c|c|c|}
\hline & \multirow{2}{*}{$\begin{array}{l}\text { Calories per } \\
\text { serving } \\
\text { (i.e., } 100 \mathrm{~g} \text { or } \\
100 \mathrm{ml} \text { ) }\end{array}$} & \multirow{2}{*}{$\begin{array}{c}\text { Price per } \\
100 \\
\text { kilocalories } \\
\text { (TSh) }\end{array}$} & \multicolumn{2}{|c|}{$\begin{array}{c}\text { Daily per capita caloric } \\
\text { availability in food-insecure } \\
\text { households }\end{array}$} & \multicolumn{2}{|c|}{$\begin{array}{l}\text { Share of daily per capita } \\
\text { caloric availability in food- } \\
\text { insecure households (\%) }\end{array}$} \\
\hline & & & $\begin{array}{c}\text { Urban } \\
\text { areas }\end{array}$ & $\begin{array}{l}\text { Rural } \\
\text { areas }\end{array}$ & $\begin{array}{c}\text { Urban } \\
\text { areas }\end{array}$ & $\begin{array}{l}\text { Rural } \\
\text { areas }\end{array}$ \\
\hline All food products & & 6.6 & 2,063 & 2,045 & 100.0 & 100.0 \\
\hline Agricultural products & 206 & 5.9 & 741 & 939 & 35.9 & 45.9 \\
\hline Cereals & 319 & 3.1 & 233 & 314 & 11.3 & 15.4 \\
\hline Maize & 252 & 3.0 & 212 & 251 & 10.3 & 12.3 \\
\hline Sorghum & 339 & 3.2 & 6 & 25 & 0.3 & 1.2 \\
\hline Millet & 361 & 3.9 & 4 & 5 & 0.2 & 0.2 \\
\hline Rice & 362 & 3.5 & 8 & 16 & 0.4 & 0.8 \\
\hline Wheat \& barley & 330 & 3.7 & 3 & 17 & 0.1 & 0.8 \\
\hline
\end{tabular}

\footnotetext{
${ }^{5}$ In contrast, the calorie-income elasticity is obtained by dividing the percentage change in caloric availability by the percentage change in household income.

${ }^{6}$ Using the household surveys estimate of per capita income growth (as a proxy for per capita GDP growth) the elasticity is 0.78 (i.e., 1.03/1.32; see Appendix C).
} 
Table 2. Continued.

\begin{tabular}{|c|c|c|c|c|c|c|}
\hline & \multirow{2}{*}{$\begin{array}{l}\text { Calories per } \\
\text { serving } \\
\text { (i.e., } 100 \mathrm{~g} \text { or } \\
100 \mathrm{ml} \text { ) }\end{array}$} & \multirow{2}{*}{$\begin{array}{l}\text { Price per } \\
100 \\
\text { kilocalories } \\
\text { (TSh) }\end{array}$} & \multicolumn{2}{|c|}{$\begin{array}{c}\text { Daily per capita caloric } \\
\text { availability in food-insecure } \\
\text { households }\end{array}$} & \multicolumn{2}{|c|}{$\begin{array}{l}\text { Share of daily per capita } \\
\text { caloric availability in food- } \\
\text { insecure households (\%) }\end{array}$} \\
\hline & & & $\begin{array}{l}\text { Urban } \\
\text { areas }\end{array}$ & $\begin{array}{l}\text { Rural } \\
\text { areas }\end{array}$ & $\begin{array}{l}\text { Urban } \\
\text { areas }\end{array}$ & $\begin{array}{l}\text { Rural } \\
\text { areas }\end{array}$ \\
\hline Root crops & 178 & 4.1 & 142 & 345 & 6.9 & 16.9 \\
\hline Cassava & 237 & 3.5 & 73 & 106 & 3.5 & 5.2 \\
\hline Other roots & 158 & 4.4 & 69 & 239 & 3.3 & 11.7 \\
\hline Pulses \& oilseeds & 443 & 8.7 & 272 & 178 & 13.2 & 8.7 \\
\hline Pulses & 260 & 9.4 & 94 & 101 & 4.6 & 4.9 \\
\hline Coconuts & 70 & 9.4 & 28 & 5 & 1.4 & 0.2 \\
\hline Oilseeds & 594 & 9.4 & 150 & 72 & 7.3 & 3.5 \\
\hline Horticulture & 49 & 18.3 & 93 & 101 & 4.5 & 4.9 \\
\hline Plantains & 116 & 5.0 & 38 & 68 & 1.8 & 3.3 \\
\hline Fruits & 60 & 12.2 & 26 & 10 & 1.3 & 0.5 \\
\hline Vegetables & 43 & 49.0 & 29 & 23 & 1.4 & 1.1 \\
\hline Cashews & 589 & 6.2 & 1 & 1 & 0.0 & 0.0 \\
\hline Animal products & 259 & 22.4 & 150 & 95 & 7.3 & 4.6 \\
\hline Cattle & 252 & 20.7 & 103 & 48 & 5.0 & 2.3 \\
\hline Poultry & 226 & 37.4 & 9 & 7 & 0.4 & 0.3 \\
\hline Other livestock & 338 & 16.7 & 6 & 21 & 0.3 & 1.0 \\
\hline Fish & 169 & 25.6 & 32 & 19 & 1.6 & 0.9 \\
\hline Processed foods & 232 & 6.1 & 1,068 & 983 & 51.8 & 48.1 \\
\hline Meat & 289 & 16.0 & 42 & 39 & 2.0 & 1.9 \\
\hline Maize milling & 362 & 3.6 & 517 & 663 & 25.1 & 32.4 \\
\hline Rice milling & 174 & 18.3 & 177 & 54 & 8.6 & 2.6 \\
\hline Other milling & 256 & 5.0 & 40 & 133 & 1.9 & 6.5 \\
\hline Other foods & 261 & 28.0 & 114 & 32 & 5.5 & 1.6 \\
\hline Refined sugar & 222 & 11.2 & 166 & 52 & 8.0 & 2.5 \\
\hline Beverages & 43 & 26.6 & 12 & 10 & 0.6 & 0.5 \\
\hline Prepared meals & 91 & 18.0 & 104 & 28 & 5.0 & 1.4 \\
\hline
\end{tabular}

Source: Authors' calculations using HBS 2000-2001 (NBS 2002) and Lukmanji et al. (2008).

Note: For the purpose of this table, food insecure is defined as the bottom 40 percent of the population as ranked by adult equivalent per capita caloric availability.

Identifying trade-offs between growth, poverty, and nutrition outcomes pose a serious challenge for governments designing their development strategies. The use of a model that captures detailed consumption patterns and income sources of households (specifically the linkages between households and different agricultural activities) is ideally suited to exploring policy scenarios.

The next section replicates Tanzania's current growth path using an economywide modeling framework and then assesses the role of economic growth in determining poverty and nutrition outcomes based on caloric availability. 


\section{POVERTY REDUCTION UNDER TANZANIA'S CURRENT GROWTH PATH}

The previous section reviewed current patterns of agricultural growth. In this section we calibrate the DCGE model to replicate recent production trends and consider the impact of this "baseline" growth scenario on poverty and caloric availability. The model includes 58 sectors (half in agriculture and agroprocessing). Agriculture is further disaggregated across 20 subnational regions and small- and largescale farmers. ${ }^{7}$ This spatial dimension of the model captures different cropping patterns and agroecological conditions within the country. The core dataset of the model is a 2007 social accounting matrix (SAM) that reconciles various data sources, including national accounts and household survey data. Information on crop production and livestock is from the 2002-2003 agricultural sample census (MINAG 2004, 2006). Nonagricultural production and employment data was compiled from the HBS 2000-2001 (NBS 2002). On the demand side, information on industrial technologies (e.g., intermediate and factor demand) was taken from an earlier SAM for Tanzania (Thurlow and Wobst 2003). Finally, the income and expenditure patterns and income elasticities for the various farm and nonfarm household groups in the model were estimated using HBS 2000-2001. The detailed economywide structure of the DCGE model therefore allows us to estimate in a consistent framework how changes in production and trade influence other producers through various factor and product markets and generate incomes for different household groups, thus affecting their poverty status and caloric availability.

Columns 6 and 7 in Table 3 show observed production growth rates for 2000-2007 and modeled growth rates in the baseline scenario. Using maize as an example, national production in the baseline scenario grows at 2.11 percent per year during 2009-2015, which is similar to the 2.08 percent annual growth rate observed during 2000-2007. This is partly achieved by allowing total harvested land area in Tanzania to expand at 2 percent per year during 2009-2015. The model endogenously allocates available land in each of the 20 regions across crops in order to maximize returns. We then exogenously increase total factor productivity (TFP) for each crop and region in order to achieve the targeted production growth rate. This causes crop land yields to change. For example, maize yields rise from 0.91 to 1.02 tons per hectare during 2009-2015 (i.e., the annual yield growth rate of 1.45 percent shown in column 2). This process of targeting production trends is repeated for each crop and livestock subsector. We also target nonagricultural sector GDP growth rates using trends from national accounts for 1998-2007 (MOFEA 2008).

\footnotetext{
${ }^{7}$ The 20 regions are grouped into eight zones for reporting (see Table A.2 and Figure A.1 in the appendix).
} 
Table 3. Crop yields and area and production outcomes under the baseline and agriculture scenarios (national level)

\begin{tabular}{|c|c|c|c|c|c|c|c|c|c|}
\hline & \multicolumn{4}{|c|}{$\begin{array}{c}\text { Crop yields } \\
\text { (exogenous: imposed on the model) }\end{array}$} & \multicolumn{5}{|c|}{$\begin{array}{l}\text { Production quantity } \\
\text { (endogenous: results from the model) }\end{array}$} \\
\hline & $\begin{array}{l}\text { Initial } \\
\text { level } \\
\mathrm{mt} / \mathrm{ha} \\
2009\end{array}$ & $\begin{array}{c}\text { Baseline } \\
\text { scenario } \\
\text { growth rate } \\
\% \\
2009-2015 \\
\end{array}$ & $\begin{array}{l}\text { Agriculture } \\
\text { scenario } \\
\text { target level } \\
\text { mt/ha } \\
2015\end{array}$ & $\begin{array}{c}\text { Agriculture } \\
\text { scenario } \\
\text { growth rate } \\
\% \\
2009-2015\end{array}$ & $\begin{array}{c}\begin{array}{c}\text { Initial } \\
\text { level }\end{array} \\
1,000 \mathrm{mt} \\
2009\end{array}$ & $\begin{array}{c}\text { Observed } \\
\text { growth } \\
\text { trends } \\
\% \\
2000-2007\end{array}$ & $\begin{array}{c}\text { Baseline } \\
\text { scenario } \\
\text { growth rate } \\
\% \\
2009-2015 \\
\end{array}$ & $\begin{array}{l}\text { Agriculture } \\
\text { scenario } \\
\text { target level } \\
1,000 \mathrm{mt} \\
2015\end{array}$ & $\begin{array}{c}\text { Agriculture } \\
\text { scenario } \\
\text { growth rate } \\
\% \\
2009-2015\end{array}$ \\
\hline \multicolumn{10}{|l|}{ Cereals } \\
\hline Maize & 0.91 & 1.45 & 1.24 & 3.94 & 2,508 & 2.08 & 2.11 & 3,593 & 4.60 \\
\hline Sorghum & 0.78 & 1.57 & 0.93 & 2.19 & 534 & 3.31 & 3.35 & 751 & 4.36 \\
\hline Millet & 0.50 & -2.85 & 0.50 & 0.08 & 144 & 0.17 & 1.02 & 186 & 3.23 \\
\hline Rice & 2.20 & 4.00 & 3.09 & 4.30 & 1,251 & 6.24 & 5.55 & 1,974 & 5.86 \\
\hline Wheat \& barley & 1.40 & 7.08 & 2.47 & 7.36 & 116 & 8.49 & 8.68 & 231 & 8.97 \\
\hline \multicolumn{10}{|l|}{ Root crops } \\
\hline Cassava & 8.57 & 2.52 & 11.13 & 3.32 & 5,737 & 3.54 & 3.07 & 7,972 & 4.20 \\
\hline Other roots & 2.47 & 5.16 & 3.72 & 5.25 & 1,296 & 5.26 & 3.87 & 1,887 & 4.81 \\
\hline \multicolumn{10}{|l|}{ Pulses \& oilseeds } \\
\hline Pulses & 0.53 & -6.97 & 0.38 & -4.05 & 482 & -4.32 & -1.90 & 498 & 0.42 \\
\hline Coconuts & 1.15 & -1.41 & 1.18 & 0.31 & 372 & 0.00 & 0.07 & 429 & 1.81 \\
\hline Oilseeds & 0.70 & 4.49 & 0.98 & 4.33 & 272 & 5.01 & 4.88 & 432 & 5.94 \\
\hline \multicolumn{10}{|l|}{ Horticulture } \\
\hline Plantains & 1.74 & -1.54 & 1.79 & 0.30 & 580 & 0.12 & 0.89 & 706 & 2.49 \\
\hline Fruits & 5.58 & 12.41 & 13.59 & 11.76 & 787 & 11.98 & 6.94 & 1,388 & 7.35 \\
\hline Vegetables & 6.55 & -0.80 & 7.55 & 1.79 & 1,180 & 0.22 & 0.37 & 1,485 & 2.92 \\
\hline \multicolumn{10}{|l|}{ Export crops } \\
\hline Coffee & 0.37 & -2.41 & 0.51 & 4.05 & 53 & -0.03 & -0.95 & 82 & 5.61 \\
\hline Cashews & 0.81 & -5.97 & 0.81 & 0.00 & 68 & -2.12 & -4.56 & 76 & 1.49 \\
\hline Cotton & 0.73 & 7.71 & 1.34 & 7.88 & 225 & 9.49 & 9.33 & 465 & 9.50 \\
\hline Sisal & 0.52 & 1.89 & 0.69 & 3.48 & 25 & 3.60 & 3.41 & 37 & 5.03 \\
\hline Sugarcane & 19.22 & 7.66 & 36.04 & 8.18 & 340 & 8.47 & 9.27 & 718 & 9.80 \\
\hline Tea & 1.73 & 2.21 & 2.34 & 3.82 & 34 & 3.80 & 3.74 & 52 & 5.37 \\
\hline Tobacco & 0.66 & 10.33 & 1.46 & 10.38 & 23 & 11.39 & 11.98 & 58 & 12.03 \\
\hline Other crops & 0.51 & -0.27 & 0.59 & 1.82 & 17 & 1.76 & 1.22 & 22 & 3.34 \\
\hline
\end{tabular}

Source: Results from the Tanzania DCGE and microsimulation model. Observed trends are from FAO (2009) and MINAG (2006). Initial yields and production quantities are results from the DCGE model after applying observed production trends for 2000-2007 to the model's 2007 base year.

Note: $\mathrm{mt}$ is million tons; ha is hectare 
Table 4 shows average annual agricultural GDP growth after replicating crop-level production trends. The agricultural GDP growth rate is 4 percent under the baseline scenario for 2009-2015. This suggests that the agricultural growth rate reported in national accounts for 1998-2007 (i.e., 4.4 percent) is broadly consistent with subsector production trends. The GDP growth rate of crop agriculture, for example, is 4.23 percent per year under the baseline scenario, compared with the observed 4.76 percent reported in national accounts. Thus, in line with recent trends, agricultural growth in the baseline scenario is driven by strong growth in crop agriculture and more modest growth in livestock. National economic growth, however, is driven by a rapid expansion of industry and services. Manufacturing is partly constrained by slower agricultural growth, which limits upstream food processing. Agroprocessing, on the other hand, benefits from fast growth of cotton and tobacco. Ultimately, total GDP grows at 6.17 percent per year under the baseline scenario, which is broadly consistent with the 6.57 percent annual growth during 1998-2007.

Table 4. GDP growth rates in the baseline and agriculture scenarios

\begin{tabular}{|c|c|c|c|c|c|c|}
\hline & \multicolumn{2}{|c|}{ Share of total (\%) } & \multicolumn{3}{|c|}{ Average annual growth rate (\%) } & \multirow{3}{*}{$\begin{array}{c}\text { Change } \\
\text { from } \\
\text { baseline } \\
\text { (\% point) } \\
2015\end{array}$} \\
\hline & Total GDP & $\begin{array}{l}\text { Agricultural } \\
\text { GDP }\end{array}$ & & $\begin{array}{l}\text { Baseline } \\
\text { scenario }\end{array}$ & $\begin{array}{l}\text { Agriculture } \\
\text { scenario }\end{array}$ & \\
\hline & 2009 & 2009 & 2015 & 2009-2015 & 2009-2015 & \\
\hline Total GDP & 100.00 & & 6.57 & 6.17 & 6.83 & $\underline{0.66}$ \\
\hline Agriculture & $\underline{31.84}$ & $\underline{100.00}$ & $\underline{4.40}$ & 3.97 & 5.87 & 1.90 \\
\hline Crop agriculture & 22.28 & 69.99 & 4.76 & 4.23 & 6.33 & 2.10 \\
\hline Cereals & 8.32 & 26.12 & - & 4.95 & 6.91 & 1.96 \\
\hline Root crops & 3.27 & 10.28 & - & 4.42 & 5.87 & 1.45 \\
\hline Pulses \& oilseeds & 2.71 & 8.51 & - & 0.64 & 3.05 & 2.41 \\
\hline Horticulture & 5.20 & 16.32 & - & 2.62 & 5.02 & 2.41 \\
\hline Export crops & 2.79 & 8.76 & - & 7.24 & 9.75 & 2.51 \\
\hline Livestock & 5.54 & 17.39 & 3.30 & 3.24 & 4.76 & 1.51 \\
\hline Other agriculture & 4.02 & 12.62 & 4.12 & 3.47 & 4.75 & 1.28 \\
\hline Mining & 3.93 & & 14.39 & 12.36 & 12.34 & -0.02 \\
\hline Manufacturing & $\overline{8.84}$ & & 7.60 & 6.93 & 7.71 & $\underline{0.78}$ \\
\hline Food processing & $\overline{4.03}$ & & - & $\overline{4.44}$ & $\overline{6.58}$ & $\overline{2.14}$ \\
\hline Other agroprocessing & 2.65 & & - & 8.63 & 8.77 & 0.14 \\
\hline Other industry & $\underline{10.39}$ & & $\underline{8.25}$ & $\underline{7.05}$ & $\underline{7.02}$ & $\underline{-0.03}$ \\
\hline Services & $\overline{45.01}$ & & $\overline{7.07}$ & $\underline{6.51}$ & $\underline{6.63}$ & $\underline{0.12}$ \\
\hline Crop and livestock GDP & 27.82 & $\underline{87.38}$ & & 4.03 & 6.02 & 1.98 \\
\hline Western & 4.45 & $\overline{13.97}$ & & $\overline{5.43}$ & $\overline{6.76}$ & $\overline{1.33}$ \\
\hline Lake & 5.99 & 18.83 & & 3.54 & 5.32 & 1.77 \\
\hline South West & 2.74 & 8.60 & & 2.49 & 5.01 & 2.52 \\
\hline Highlands & 2.28 & 7.16 & & 4.81 & 7.17 & 2.36 \\
\hline South East & 1.10 & 3.45 & & 2.00 & 5.21 & 3.20 \\
\hline Eastern & 3.75 & 11.78 & & 4.84 & 6.60 & 1.77 \\
\hline Central & 1.43 & 4.50 & & 3.31 & 5.33 & 2.02 \\
\hline Northern & 6.08 & 19.09 & & 3.79 & 6.08 & 2.30 \\
\hline
\end{tabular}

Source: Results from the Tanzania DCGE and microsimulation model. Observed trends from MOFEA (2008).

Note: Regional GDP only includes crops and livestock since the fisheries and forestry subsectors are not disaggregated across subnational regions in the model.

The model predicts changes in households' consumption spending on different commodities for a range of representative household groups (i.e., regional rural/urban farm/nonfarm households). Household group consumption changes in the DCGE model are passed down to individual households in the survey 
that make up that group. Poverty and calorie deficiency rates are then recomputed using the updated survey data. ${ }^{8}$ The Tanzania model estimates that, under the baseline scenario, the increase in average per capita GDP by 3.59 percent each year (i.e., assuming 2.5 percent population growth) will cause the national poverty headcount to decline from 40.0 percent in 2007 to 31.1 by 2015 (see Figure 2). ${ }^{9}$ This is a 3.09 percent annual decline in the poverty rate and so implies a poverty-growth elasticity of 0.86 (i.e., $3.09 / 3.59$ ). This is slightly above the 0.76 poverty-growth elasticity estimated by the household surveys for 2001-2007. However, the model's results are reasonably consistent with the distributional changes observed for this period.

Figure 2. National poverty rate under alternative agricultural growth scenarios

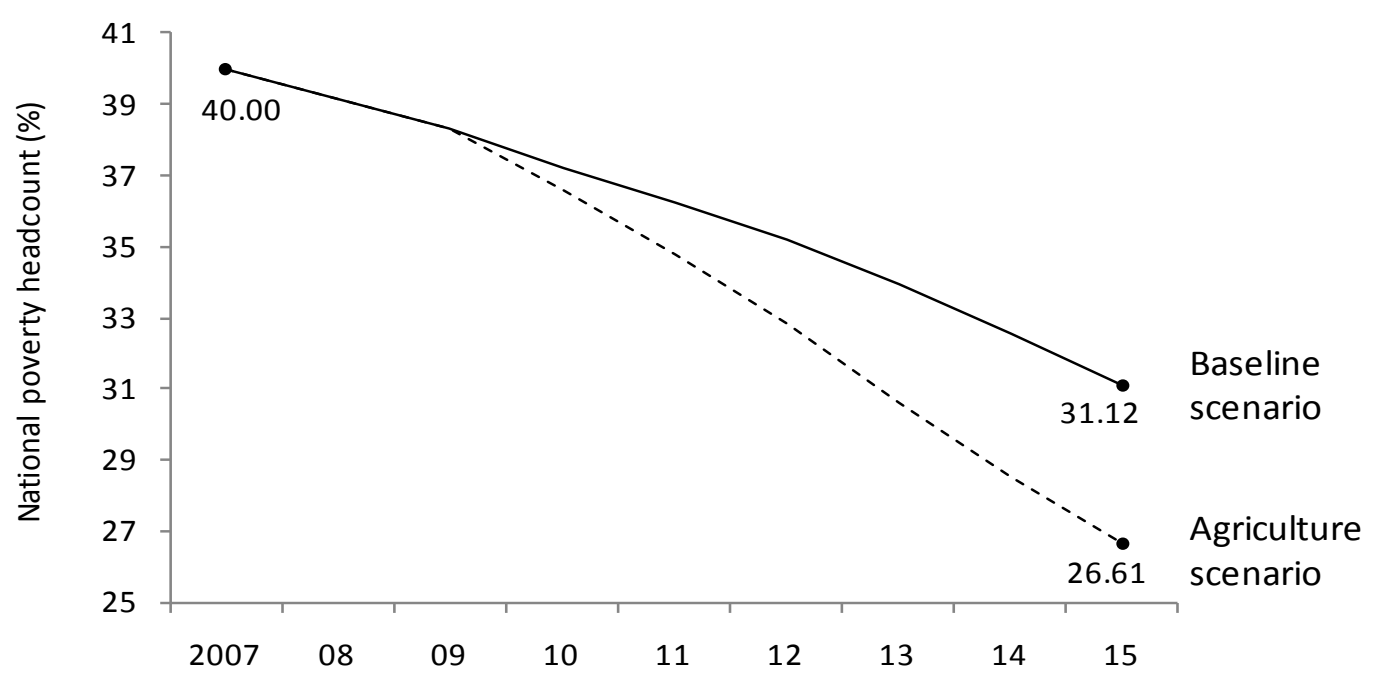

Source: Results from the Tanzania DCGE and microsimulation model.

The baseline scenario offers two insights into the current growth-poverty relationship in Tanzania. First, the level of agricultural GDP growth reported in national accounts is consistent with subsector-level production trends. Second, the distributional impact of the current growth path is consistent with the small change in inequality reported in the household surveys between 2001 and 2007 (i.e., the model and surveys produce similar poverty-growth elasticities). These two findings suggest that the level of nonagricultural growth is overestimated in national accounts, the rate of poverty reduction is underestimated in the household surveys, or both. ${ }^{10}$

A third finding of the baseline scenario is that the composition of economic growth, particularly agricultural growth, has large implications for the rate of poverty reduction. Rapid growth in traditional exports during 2000-2007 mainly benefited farmers in the regions where these crops are grown.

Similarly, the expansion of certain crops, such as sugarcane and wheat, was more likely to benefit largerscale farmers, who in turn are less likely to be poor. In contrast, declining per capita maize production slowed down real per capita income growth for poorer farmers throughout the country.

The unevenness of growth is evident in Table 4, which shows changes in regional agricultural GDP under the baseline scenario. Agricultural GDP growth is highest in the Western, Northern, and Eastern zones, where the country produces most of its fast-growing sugarcane, tobacco, and cotton.

\footnotetext{
${ }^{8}$ See Appendix B for a more detailed description of the microsimulation module.

${ }^{9}$ The poverty line is defined at the 40th percentile of per capita expenditure for 2007 , such that the bottom two expenditure quintiles of the population are defined as poor.

${ }^{10}$ See Appendix $\mathrm{C}$ for a more detailed discussion of measuring the poverty-growth relationship in Tanzania and possible discrepancies between national accounts and household surveys.
} 
Growth is slowest in the South East zone, where farmers rely more heavily on slower-growing maize, cashews, and poultry. Thus, although the overall level of agricultural GDP growth is high in Tanzania, its composition is such that it does not benefit all farmers equally, and to some extent excludes certain regions and many of country's poorer farmers. Tanzania must therefore accelerate economic growth in sectors with stronger links to poorer households and regions if it is to significantly reduce poverty. 


\section{ACCELERATING BROAD-BASED AGRICULTURAL GROWTH}

\section{Raising Agricultural Production}

In this section we use the DCGE model to accelerate agricultural growth in a wider range of subsectors than those that led the growth process during 2000-2007. More specifically, in the agriculture scenario we increase production in agriculture subsectors beyond what was achieved in the baseline scenario. We do not increase land expansion beyond its current 2 percent growth rate but rather raise productivity growth in individual subsectors (starting from 2010). Using maize as an example, we increase the annualyield growth rate from 1.45 percent under the baseline scenario to 3.94 percent under the agriculture scenario (see column 4 in Table 3). Accordingly, while current trends predict maize yields will rise from $0.91 \mathrm{million}$ tons per hectare (mt/ha) to $1.10 \mathrm{mt} / \mathrm{ha}$ during 2009-2015, in the agriculture scenario they rise to $1.24 \mathrm{mt} / \mathrm{ha}$. This means that overall maize production increases by one million tons during 2009-2015, which is twice what is expected based on current trends (see column 8 in Table 3 ). In contrast, wheat and tobacco production do not grow much faster under the agriculture scenario, because these crops already expanded rapidly under the baseline scenario. This process of improving crop yields and increasing production is repeated for all agricultural subsectors.

Annual agricultural GDP growth rises from 3.97 percent in the baseline scenario to 5.87 percent in the agriculture scenario during 2009-2015 (see column 5 in Table 4). Agricultural growth is now also more broad based, with most crops growing more rapidly. The largest improvement is in horticulture, where the previous decline in vegetable yields is now reversed. The growth rate of export crops now averages almost 10 percent per year, suggesting that there is still considerable growth potential in export agriculture. Average livestock GDP growth also rises by 1.5 percentage points. Faster agricultural growth generates strong forward linkage effects for upstream food processing, which benefits from increased supply of maize and livestock products for the grain milling and meat subsectors. There is, however, only a small increase in other agroprocessing, since tobacco refining was already growing rapidly under the baseline scenario. Overall, the expansion of agriculture and upstream sectors causes the growth rate of total national GDP to increase from 6.17 to 6.83 percent per year under the agriculture scenario.

Agricultural growth is now more evenly distributed across regions. In the baseline scenario, agricultural growth was concentrated in rice, wheat, and certain traditional export crops. In the agriculture scenario all regions benefit from broader-based growth. For example, the South East zone was the slowest growing region in the baseline scenario, with annual agricultural growth of only 2 percent. This now increases to over 5 percent per year, driven by maize, cashews, and coconuts, which are important crops for this part of the country. However, regional inequality in agricultural growth still widens, since areas like the Northern and Highlands zones benefit from faster export crop growth, particularly for coffee, tea, and sisal, which are more likely to benefit larger-scale farmers (see Table 1).

\section{Market Constraints and Price Effects}

Increasing agricultural production causes prices to fall if demand or market constraints exist. We expect prices to fall for commodities (1) whose production has increased substantially, (2) that have weak upstream intermediate linkages in the processing subsectors, and (3) that rely heavily on domestic demand and do not have many export or import substitution opportunities. Figure 3 shows changes in market prices relative to the baseline scenario. The price of maize, millet, and vegetables falls sharply because these commodities have low income elasticities. This means that the share of consumer spending on these commodities rises slower than incomes. The demand for maize, especially in urban areas, is further constrained by the capacity of upstream grain milling. A similar upstream production constraint exists for coffee, which is exported only after processing.

In contrast, rice and wheat have higher income elasticities than maize and millet, and the production of these crops does not increase as much under the agriculture scenario. Therefore, prices for these two crops actually rise as household agricultural revenues increase. Tobacco and cotton production 
also increase only slightly from their current trends, and their export-orientation means access to large foreign markets and lower demand constraints. Model results therefore reveal severe market constraints and suggest that limited upstream agroprocessing capacity is a binding constraint to sustaining agricultural growth, both for food staples and certain, more export-oriented crops.

Figure 3. Relative producer price changes under the agriculture scenario

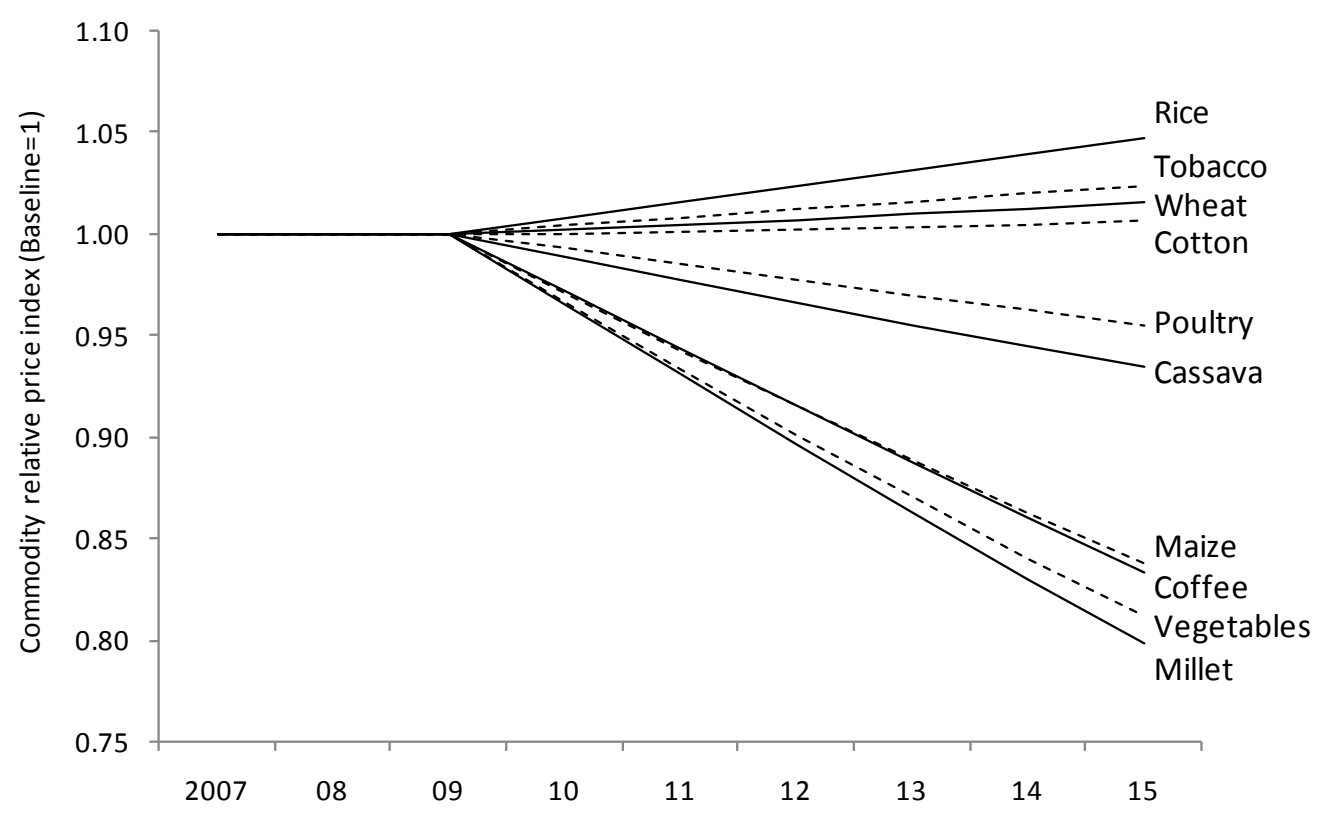

Source: Results from the Tanzania DCGE and microsimulation model.

\section{Impacts on Poverty and Caloric Availability}

The acceleration of agricultural growth to almost 6 percent per year and the spillover effects into agroprocessing causes poverty to decline by a further 4.51 percentage points by 2015 . This is shown in Figure 2, where the share of Tanzania's population under the poverty line is 26.61 percent by 2015 under the agriculture scenario, compared with 31.12 percent under the baseline scenario. Thus, taking 2.5 percent annual population growth into account, achieving the productivity improvements in Table 2 lifts an additional 1.74 million people above the poverty line by 2015 . The acceleration of broad-based agricultural growth also strengthens the growth-poverty relationship in Tanzania. For example, the additional 2 percentage points of agricultural growth each year causes the poverty-growth elasticity to rise from 0.86 under the baseline scenario to 1.36 under the agriculture scenario. This is a result of per capita GDP now growing at 4.33 percent per year during 2009-2015 and the poverty rate declining by 5.89 percent per year (i.e., 5.89/4.33). Since we only increase agricultural growth in the agriculture scenario, the increase in the poverty-growth elasticity relative to the baseline scenario implies that broadbased agricultural growth is more pro-poor than nonagricultural growth.

All household groups in the DCGE model benefit from accelerated agricultural growth (see column 4 in Table 5). Not surprisingly, the rural poverty rate declines substantially in the agriculture scenario (i.e., by 4.96 percentage points). Poverty reduction is largest in the Northern and Central zones, where poorer households benefit from stronger growth in millet and livestock, and to a lesser extent from out-grower export crops such as coffee. Improved plantain, vegetables, and pulses production also favors poorer households in the Lake zone. In contrast, the drop in poverty is smaller in the South West zone. These households rely more heavily on nonfarm incomes, so their incomes are less affected by increased agricultural revenues. Finally, while urban and nonfarm households do not benefit directly from 
agricultural revenues, they do benefit from falling consumer prices. Even urban nonfarm households in the highest expenditure quintile spend about half of their incomes on purchased foods. More importantly, lower expenditure quintile nonfarm households spend as much as three-quarters of their income on agricultural products. Forward consumption linkages therefore explain why the urban poverty rate falls by 2.62 percentage points under the agriculture scenario.

Agricultural growth also benefits household calorie intake by increasing incomes and food availability in the country. As a result, the share of the national population consuming less than 2,550 calories per day falls by 4.15 percentage points, which is over and above the 4.23 percentage point reduction already occurring in the baseline scenario (see column 8 in Table 5). The initial elasticity between economic growth and the calorie deficiency rate was 0.681 in the baseline scenario (i.e., a 2.44 percent annual decline in the deficiency rate divided by 3.59 percent per capita GDP growth). Model results show that accelerating broad-based agricultural growth greatly enhances the growth-calorie relationship, with the elasticity rising to 1.48 in the agriculture scenario, driven primarily by increased production and consumption of calorie-rich maize, pulses, and millet. 
Table 5. Changes in poverty headcount and calorie deficiency rates in the model

\begin{tabular}{|c|c|c|c|c|c|c|c|c|}
\hline & \multicolumn{4}{|c|}{ Poverty headcount rate (\%) } & \multicolumn{4}{|c|}{ Calorie deficiency rate $(\%)$} \\
\hline & \multirow{2}{*}{$\begin{array}{c}\text { Initial } \\
\text { poverty rate } \\
2007 \\
\end{array}$} & \multicolumn{2}{|c|}{ Final poverty rate } & \multirow{2}{*}{$\begin{array}{l}\text { Change from } \\
\text { baseline } \\
\text { (\% point) } \\
2015\end{array}$} & \multirow{2}{*}{$\begin{array}{l}\text { Initial calorie } \\
\text { deficiency } \\
\text { rate } \\
2007 \\
\end{array}$} & \multicolumn{2}{|c|}{ Final calorie deficiency rate } & \multirow{2}{*}{$\begin{array}{c}\text { Change from } \\
\text { baseline } \\
\text { (\% point) } \\
2015\end{array}$} \\
\hline & & $\begin{array}{l}\text { Baseline } \\
\text { scenario } \\
2015 \\
\end{array}$ & $\begin{array}{c}\text { Agriculture } \\
\text { scenario } \\
2015 \\
\end{array}$ & & & $\begin{array}{c}\text { Baseline } \\
\text { scenario } \\
2015 \\
\end{array}$ & $\begin{array}{c}\text { Agriculture } \\
\text { scenario } \\
2015 \\
\end{array}$ & \\
\hline National & 40.00 & 31.12 & 26.61 & -4.51 & 23.56 & 19.33 & 15.18 & -4.15 \\
\hline Rural & 44.74 & 35.00 & 30.04 & -4.96 & 22.30 & 18.16 & 13.97 & -4.19 \\
\hline Urban & 20.16 & 14.80 & 12.17 & -2.62 & 28.82 & 24.23 & 20.25 & -3.98 \\
\hline Nonfarm & 24.93 & 19.43 & 16.40 & -3.04 & 30.05 & 26.13 & 20.67 & -5.46 \\
\hline Farm & 43.46 & 33.79 & 28.94 & -4.85 & 22.07 & 17.78 & 13.92 & -3.85 \\
\hline Western & 39.65 & 27.70 & 23.61 & -4.10 & 14.78 & 10.17 & 7.51 & -2.66 \\
\hline Lake & 50.46 & 41.87 & 36.54 & -5.33 & 27.38 & 22.80 & 19.95 & -2.85 \\
\hline South West & 36.11 & 31.31 & 29.36 & -1.95 & 17.78 & 15.45 & 12.71 & -2.74 \\
\hline Highlands & 42.21 & 25.04 & 20.14 & -4.90 & 20.20 & 16.27 & 12.81 & -3.46 \\
\hline South East & 37.58 & 25.46 & 21.29 & -4.17 & 23.85 & 19.15 & 14.16 & -5.00 \\
\hline Eastern & 37.65 & 29.95 & 26.39 & -3.56 & 27.67 & 23.04 & 18.99 & -4.05 \\
\hline Central & 58.20 & 47.27 & 40.80 & -6.46 & 22.66 & 15.41 & 11.71 & -3.70 \\
\hline Northern & 40.47 & 33.71 & 26.62 & -7.09 & 23.76 & 21.07 & 13.84 & -7.23 \\
\hline
\end{tabular}

Source: Results from the Tanzania DCGE and microsimulation model. 
The distribution of changes in nutritional outcomes differs from that of poverty outcomes. Most striking perhaps is the larger reduction in the calorie deficiency rate for urban nonfarm households compared with rural households. Urban households initially have a higher calorie deficiency rate than rural households. This may seem puzzling since urban households typically earn higher incomes. This relates partly to the fact that urban households face a higher cost of living than their rural counterparts. ${ }^{11}$ However, it may also reflect an underestimation of urban household caloric availability, which is related to the fact that these households consume more food from street vendors and restaurants. Such expenditures are more likely to be misreported; in addition, attaching a caloric content to prepared foods is difficult.

Nevertheless, increased production and falling prices for key food staples appear to greatly improve urban households' nutritional status. Even though rural households benefit from the same declines in prices, lower prices also mean lower returns to agricultural activities and a decline in rural incomes. As net consumers of agricultural and food products, urban households therefore benefit more than rural households. Furthermore, while all households benefit from increased maize availability, urban nonfarm households, compared with rural households, also derive a larger share of their calorie intake from pulses, vegetables, and livestock products. These crops grow particularly fast under the agriculture scenario.

In summary, accelerating agricultural growth greatly strengthens both the growth-poverty and growth-nutrition relationship in Tanzania. This is driven by the broader base of agricultural growth, which allows the production of key calorie-laden food crops, such as maize and millet, to expand. These crops are also more widespread in Tanzania, implying greater participation of smallholder farmers in a larger number of regions within the country. Ultimately, our model results indicate that agricultural growth is substantially more pro-poor than nonagricultural growth, as evidenced by the large increase in the overall poverty-growth elasticity in the agriculture scenario. At the same time it has the ability to improve caloric availability due to increased availability of food at lower prices across the spectrum of households.

\footnotetext{
${ }^{11}$ For example, our estimates show that urban households in the bottom 20 percent of caloric availability obtain an average of 1,538 kilocalories at a cost of TSh 207 per day, while rural households spend TSh 125 for a similar amount of calories. Price variations also explain the differences in the composition of caloric availability across urban and rural food-insecure households (see columns 3 to 6 in Table 2).
} 


\section{COMPARING ALTERNATIVE SOURCES OF AGRICULTURAL GROWTH}

In this section we compare alternative sources of growth in terms of their effectiveness in reducing poverty, improving households' calorie intake, and stimulating overall economic growth in the country. Agricultural subsectors can have different impacts on development outcomes for a variety of reasons. First, certain subsectors are already large, so small-yield improvements can have large implications for agricultural and national economic growth. Second, smaller subsectors may have large growth potentials and therefore can contribute to overall growth through their rapid expansion. Third, some sectors are more effective at reducing poverty because either they have stronger linkages to poorer households' income-generation process or they produce products that poorer households consume intensively. Fourthly and similarly, some subsectors produce products that are particularly important for households' nutritional status, such as those that are cost-effective sources of calories and other minerals, those that are consumed intensively by nutrient-deficient households, or both. Finally, some agricultural subsectors have stronger linkages to upstream processing, so expanding production in these subsectors generates more growth outside of agriculture. We consider these five criteria when prioritizing subsectors.

Table 6 presents poverty-growth elasticities for individual subsectors (see columns 1 and 2). Each subsector grew at a different rate in the agriculture scenario. To produce comparable indicators, we normalize elasticities by assuming that all of the additional per capita GDP generated in the agriculture scenario comes entirely from each individual subsector (i.e., we neutralize size effects). The three highest normalized poverty-growth elasticities are for growth led by maize, sorghum/millet, and root crops. This is because these crops are important expenditure items for households just below the poverty line. They are also crops that are grown more intensively by poorer farm households. In contrast, the elasticity for rice- and wheat-led growth is lower, because these crops are grown in specific parts of the country and, in the case of wheat, by larger-scale farmers who are less likely to be poor.

Table 6. Poverty-growth and calorie-growth elasticities under alternative growth scenarios

\begin{tabular}{lrrrr}
\hline & \multicolumn{3}{c}{$\begin{array}{c}\text { Percentage change in poverty or calorie index caused by 1 percent } \\
\text { growth in total GDP led by the following crops and subsectors }\end{array}$} \\
\cline { 2 - 5 } & \multicolumn{2}{c}{$\begin{array}{c}\text { Poverty headcount } \\
\text { Modeled }\end{array}$} & Normalized & \multicolumn{2}{c}{$\begin{array}{c}\text { Calorie deficiency headcount } \\
\text { Modeled }\end{array}$} & Normalized \\
\hline Baseline scenario & -0.863 & - & -0.681 & - \\
Agriculture scenario & -1.361 & -1.361 & -1.479 & -1.479 \\
Maize-led growth & -1.088 & -1.494 & -1.105 & -1.868 \\
Sorghum- and millet-led & & & & \\
growth & -0.965 & -1.472 & -0.817 & -1.492 \\
Rice- and wheat-led growth & -0.927 & -1.346 & -0.708 & -0.888 \\
Roots-led growth & -0.959 & -1.446 & -0.756 & -1.136 \\
Pulses- and oilseeds-led & & & & -1.825 \\
growth & -1.022 & -1.416 & -1.010 & -1.007 \\
Horticulture-led growth & -1.009 & -1.357 & -0.777 & -0.831 \\
Export crop-led growth & -0.999 & -1.411 & -0.718 & -0.680 \\
Livestock-led growth & -1.003 & -1.322 & -0.681 & -0.905 \\
Other agriculture-led growth & -0.964 & -1.353 & -0.727 & \\
\hline
\end{tabular}

Source: Results from the Tanzania DCGE and microsimulation model.

Note: Normalized elasticities assume that the increase in GDP in the agriculture now comes entirely from individual sectors (i.e., the elasticities assume the same absolute change in per capita GDP).

Table 6 also shows normalized calorie deficiency-growth elasticities. Model results indicate that maize and sorghum/millet are two of the more effective crops at improving household calorie intake per unit of growth. However, root crops are less effective than pulses/oilseeds, since the latter have higher 
calorie contents and are a more important source of calories for both rural and urban households. Livestock has the lowest elasticity in spite of the high calorie content of meat products. This is because livestock products are an expensive source of calories and are consumed less intensively than other calorie sources by lower-income households.

Table 7 measures each sector's contribution to agricultural and total GDP and compares the economywide growth-linkage effects. For instance, maize-led growth generates TSh 237.8 billion additional agricultural GDP (measured in 2007 prices). Total GDP increases by more than this amount due to backward and forward production and consumption linkages. For example, higher maize production reduces input prices for grain milling and for animal feedstock in the meat-processing sectors. It also increases households' real incomes that are then spent on nonagricultural commodities. Total GDP increases by TSh 262.6 billion, which means that for every shilling increase in agricultural GDP driven by maize-led growth, there is an additional 0.10 shilling increase in nonagricultural GDP (i.e., a multiplier effect of 1.10). These results suggest that livestock, pulses/oilseeds, and sorghum/millet have the largest growth-linkage effects. Livestock has strong linkages to upstream meat processing, which is the largest of the food-processing subsectors. In contrast, some export crops are exported without much processing, such as tea and cashew nuts. This lowers these crops' upstream growth linkages. Finally, the comparatively low linkage effect of maize highlights its upstream processing constraints, which explains why the market price of maize falls dramatically in the agriculture sector. However, even though maize has smaller linkage effects, its initial size means that it still contributes the most to total GDP.

Table 7. Economywide growth-linkage effect of agriculture under the agriculture scenario

\begin{tabular}{|c|c|c|c|c|c|c|}
\hline & \multirow{2}{*}{$\begin{array}{c}\text { Sector's } \\
\text { GDP in } \\
2009 \\
(2007 \\
\text { bil. TSh) }\end{array}$} & \multicolumn{2}{|c|}{$\begin{array}{c}\text { Sectoral growth rates, } \\
2009-2015(\%)\end{array}$} & \multicolumn{2}{|c|}{$\begin{array}{l}\text { Additional GDP relative to } \\
\text { baseline (2007 bil. TSh) }\end{array}$} & \multirow{2}{*}{$\begin{array}{l}\text { Growth- } \\
\text { linkage } \\
\text { effect }\end{array}$} \\
\hline & & $\begin{array}{l}\text { Baseline } \\
\text { scenario }\end{array}$ & $\begin{array}{c}\text { Sector } \\
\text { scenario }\end{array}$ & $\begin{array}{c}\text { Total GDP } \\
2015 \\
(1) \\
\end{array}$ & $\begin{array}{c}\text { Agric. GDP } \\
2015 \\
(2) \\
\end{array}$ & \\
\hline Maize-led growth & 893 & 2.82 & 5.69 & 262.6 & 237.8 & 1.10 \\
\hline Sorghum- and millet-led growth & 181 & 3.83 & 4.77 & 41.6 & 34.4 & 1.21 \\
\hline Rice- and wheat-led growth & 664 & 7.78 & 7.83 & 3.0 & 2.5 & 1.19 \\
\hline Roots-led growth & 679 & 4.42 & 4.98 & 38.1 & 32.5 & 1.17 \\
\hline Pulses- and oilseeds-led growth & 510 & 0.64 & 2.60 & 179.6 & 140.0 & 1.28 \\
\hline Horticulture-led growth & 1,030 & 2.62 & 4.44 & 188.4 & 160.8 & 1.17 \\
\hline Export crop-led growth & 581 & 7.24 & 9.74 & 132.7 & 115.4 & 1.15 \\
\hline Livestock-led growth & 1,121 & 3.24 & 4.51 & 200.5 & 117.7 & 1.70 \\
\hline Other agriculture-led growth & 821 & 3.47 & 4.86 & 85.7 & 80.1 & 1.07 \\
\hline
\end{tabular}

Source: Results from the Tanzania DCGE and microsimulation model.

Figure 4 summarizes the findings. The three subsectors with the highest poverty-growth and calorie-growth elasticities are placed inside the circles labeled poverty effect and nutrition effect, respectively. Similarly, we identify the three sectors contributing the most to total GDP growth, which takes into account the subsector's initial size, growth potential, and economywide linkage effect. Maize is included in the top three subsectors for all three criteria, suggesting that this crop should be afforded a high priority in the government's agricultural investment plans. Sorghum and millet, while relatively small compared with maize, rank highly on both on the criteria of reducing poverty and improving household caloric availability. However, it should be noted that maize, sorghum, and millet were identified as facing severe market constraints (see Figure 3). Therefore, to facilitate a sustained expansion of production these crops, it is essential to enhance their upstream linkages and domestic market opportunities. 
Figure 4. Prioritizing agricultural sectors for investment

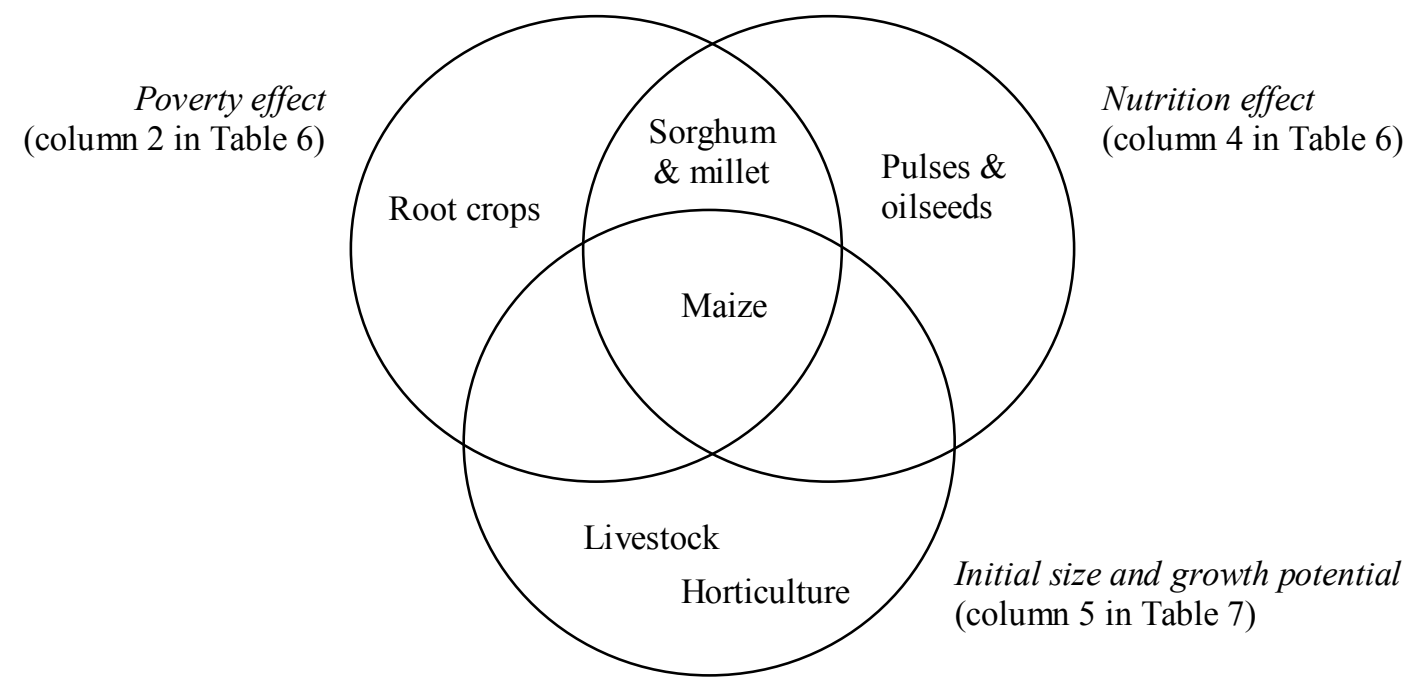

Source: Results from the Tanzania DCGE and microsimulation model. 


\section{CONCLUSIONS AND POLICY IMPLICATIONS}

Tanzania's growth performance has been commendable, with national GDP growing at over 6 percent per year since 2000. However, rapid growth has led to neither substantial reductions in poverty nor improvements in household's nutritional status. This has raised concerns about a possible decoupling of economic growth, poverty, and nutrition. Results from a regional and dynamic CGE model of Tanzania indicate that the country's low poverty-growth elasticity is primarily a result of the current structure of agricultural growth, which favors larger-scale production of rice, wheat, and traditional export crops. Accelerating agricultural growth in a wider range of subsectors than those currently leading the growth process is needed to strengthen the effectiveness of growth at reducing poverty and improving the availability of calories in households.

Evidence for Tanzania suggests that investing in research and extension has large, positive impacts on agricultural growth and household incomes (Fan et al. 2005). Econometric estimates suggest that every TSh 1 million spent on agricultural research (in 1999 prices) increases household incomes by TSh 12.5 million and lifts 40 people above the poverty line. Moreover, the returns to agricultural research are found to have higher impacts than similar investments in education and rural roads, both of which also have positive returns. Despite these high returns on investment, however, the government of Tanzania spends only a small share of its budget on agriculture. Allocations to agriculture averaged only 3 percent of the total budget during 2004-2007-a share that has also deteriorated over time (MOFEA 2008). Moreover, spending on research and extension comprises less than 15 percent of the agricultural budget. Additional spending on agriculture, particularly on research and extension, is therefore needed, along with improved efficiency in the way the ministry of agriculture spends its budget allocation.

Model results identified maize as a priority sector for investment. Empirical evidence suggests that maize yields in Tanzania are rising, thanks to the provision of extension services and farmers' increased use of improved inputs, especially fertilizer (Nkonya et al. 1997). Supporting investments in rural education are also found to encourage greater adoption of improved technologies. However, much of Tanzania's maize production is rain fed, thus making the country highly susceptible to extreme climate events and high market price volatility. In this regard, evidence suggests that lowering transaction costs through investing in rural roads would reduce price volatility in Tanzania and also increase farm gate prices, thereby enhancing returns to maize farming (Kilima et al. 2008). Our model results also identified severe market constraints facing maize production in Tanzania. Expanding upstream milling capacity would strengthen famers' access to urban consumers, who demand more processed maize, thus relieving some of the downward pressure on maize prices. Similarly, model results also suggest that opportunities exist for domestic producers to substitute for imported cereals.

Finally, the model results provided two insights into the current inconsistencies between the rapid economic growth reported in national accounts and the small improvements in poverty and caloric availability from the household surveys. First, national accounts estimate that agricultural growth is found to be consistent with subsector-level production trends. Secondly, the model and surveys produced similar estimates of the poverty-growth elasticity, suggesting that the structure of growth is consistent with only small changes in inequality. These two findings suggest that the level of nonagricultural growth is overestimated in national accounts, the rate of poverty reduction is underestimated in the household surveys, or both. Regardless of these inconsistencies, however, the model results confirm the weak relationship between economic growth, poverty, and nutrition in Tanzania. They underline the importance of encouraging broader-based economic growth in the future, with the stronger role for agriculture and food crops in particular. 


\section{APPENDIX A: SPECIFICATION OF THE DCGE MODEL}

\section{The Core General Equilibrium Model}

Table A.1 presents the equations of a simple, closed-economy dynamic computable general equilibrium (DCGE) model illustrating how sector growth is linked to market prices and household incomes in our analysis. The model is recursive dynamic and can therefore be separated into a static "within-period" component wherein producers and consumers maximize profits and utility, and a dynamic "betweenperiod" component wherein the model is updated based on the demographic model and previous period results, thereby reflecting changes in population, labor supply, and the accumulation of capital and technology.

In the static component of the model, producers in each sector $s$ and region $r$ produce a level of output $Q$ in time period $t$ by employing the factors of production $F$ under constant returns to scale (exogenous productivity $\alpha$ ) and fixed production technologies (fixed factor shares $\delta$ ) (equation 1). Profit maximization implies that factor payments $W$ are equal to average production revenues (equation 2 ).

Labor supply $L$, land supply $N$, and capital supply $K$ are fixed within a given time period, implying full employment of factor resources. Land and labor market equilibrium is defined at the regional level, so land and labor is mobile across sectors, but wages and rental rates vary by region (equation 6). National capital market equilibrium implies that capital is mobile across both sectors and regions and earns a national rental rate (i.e., regional capital returns are equalized) (equation 7).

Factor incomes are distributed to households in each region using fixed income shares based on households' initial factor endowments $\theta$ (equation 3). Total household incomes $Y$ are then either saved (based on marginal propensities to save $v$ ) or spent on consumption $C$ (according to marginal budget shares $\beta$ ) (equation 4). Savings are collected in a national savings pool and used to finance investment demand $I$ (i.e., savings-driven investment closure) (equation 5). Finally, a single price $P$ equilibrates demand and supply in national product markets, thus avoiding the necessity of modeling interregional trade flows (equation 8).

Table A.1. Simple CGE model equations

\begin{tabular}{ll}
\hline Static model equations & $Q_{s r t}=\alpha_{s r t} \cdot \prod_{f} F_{f s r t}^{\delta_{f r r}}$ \\
Production function & $W_{f r t} \cdot \sum_{s} F_{f s r t}=\sum_{s} \delta_{f s r} \cdot P_{s t} \cdot Q_{s r t}$ \\
Factor payments & $Y_{h r t}=\sum_{f s} \theta_{h f} \cdot W_{f r t} \cdot F_{f s r t}$ \\
Household income & $P_{s t} \cdot D_{h s r t}=\beta_{h s r} \cdot\left(1-v_{h r}\right) \cdot Y_{h r t}$ \\
Consumption demand & $P_{s t} \cdot I_{s t}=\rho_{s} \cdot \sum_{h r} v_{h r} \cdot Y_{h r t}$ \\
Investment demand & $\sum_{s} F_{f s r t}=L_{f r t}$ \\
Labor market equilibrium & $\sum_{s} F_{f s r t}=N_{f r t}$ \\
Land market equilibrium & $\sum_{r s} F_{f s r t}=K_{f t} \quad$ and $\quad W_{f r t}=W_{f r^{\prime} t}$ \\
Capital market equilibrium & $\sum_{h r} D_{h s r t}+I_{s t}=\sum_{r} Q_{s r t}$ \\
Product market equilibrium & fis land
\end{tabular}


Table A.1. Continued

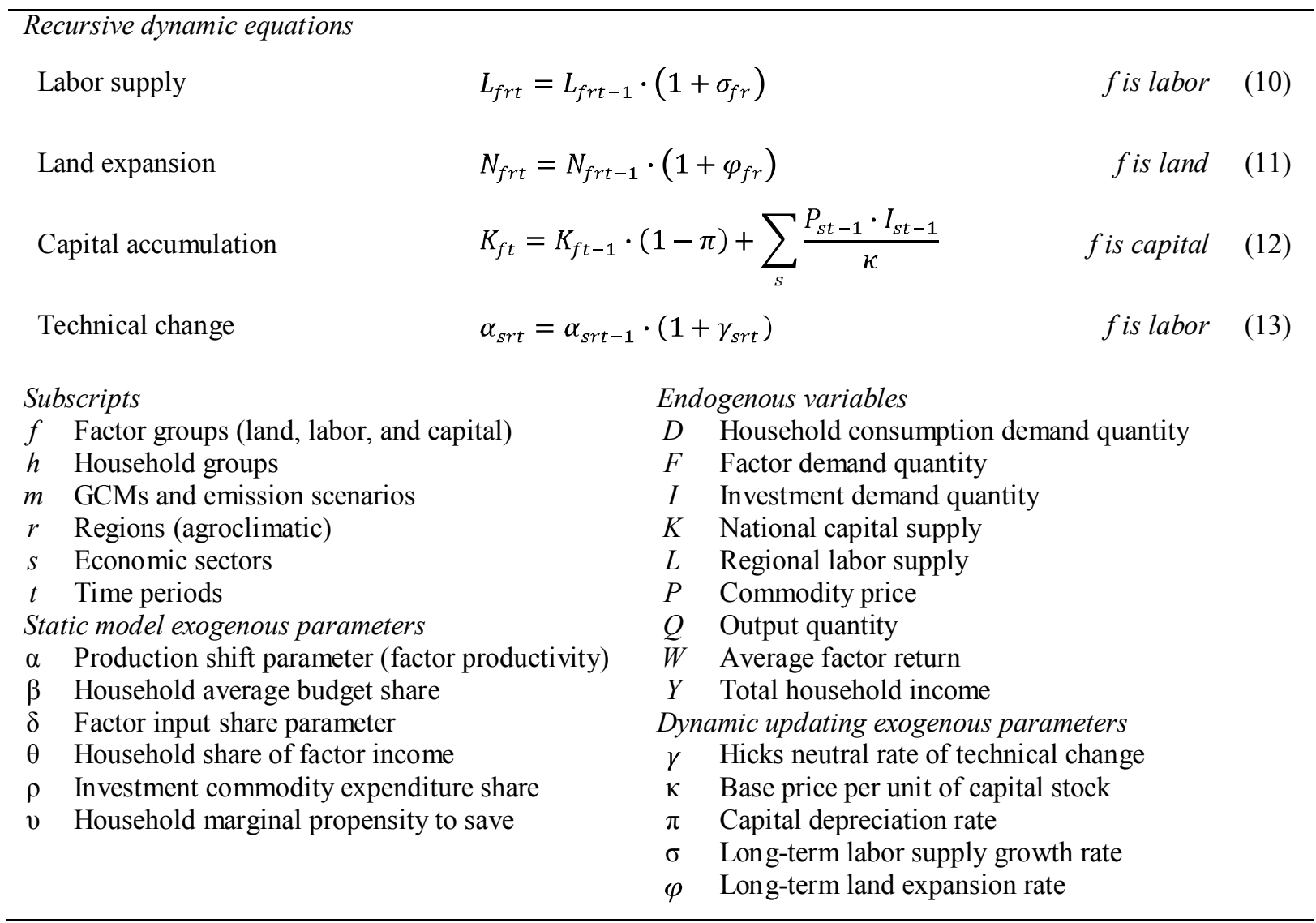

The model's variables and parameters are calibrated to observed data from a regional social accounting matrix (SAM) that captures the initial equilibrium structure of the Tanzanian economy in 2007. Parameters are then adjusted over time to reflect demographic and economic changes and the model is recalculated for a series of new equilibriums for the eight-year period 2007-2015. Three dynamic adjustments occur between periods: changes in land and labor supply, capital accumulation, and technical change.

Between periods the model is updated to reflect long-term growth rates in land supply $N$ and labor supply $L$. These are imposed through the parameters $\sigma$ and $\varphi$ (equations 9 and 10), which remain unchanged across simulations and time periods. For capital supply $K$, the model endogenously determines the national rate of accumulation (equation 11). The level of investment $I$ from the previous period is converted into new capital stocks using a fixed capital price $\kappa$. This is added to previous capital stocks after applying a fixed long-term rate of depreciation $\pi$. New capital is allocated to regions and sectors endogenously to equalize capital returns. Finally, the model captures total factor productivity through the production function's shift parameter $\alpha$. The rate of technical change $\gamma$ is determined exogenously.

To reach the production targets in our simulations, we increase the rate of technical change $\gamma$ in a particular sector. This increases production of this product $Q$ (equation 1), as well as factor demand $F$ and returns $W$ (equation 2) depending on relative factor intensities of production $\delta$. Household incomes $Y$ also rise at differing rates, depending on their relative factor endowments $\theta$ (equation 3 ). The increase in consumer demand $D$ depends on the composition of household baskets $\beta$ (equation 4 ). The overall increase in demand is then moderated in product markets through changing price $P$ (equation 9 ). Similarly, increased factor demand is constrained by total factor availability through factor returns $W$ (equations 6,7, and 8). The results of the model are therefore largely determined by the structural 
characteristics of the economy (e.g., $\beta, \delta$, and $\theta$ ), which are empirically estimated from industrial and household surveys. Given these characteristics, the model determines how production affects market prices and household incomes within a consistent economywide framework.

\section{Extensions in the Full Tanzania DCGE Model}

The above model illustrates how we link economic growth to household incomes. However, the full Tanzania model drops many of the assumptions implicit in this simplified model. Constant elasticity of substitution production functions replace Cobb-Douglas functions to allow factor substitution based on relative factor prices (i.e., $\delta$ is no longer fixed). The full model identifies 58 sectors (see Table A.2), and agriculture is disaggregated across 20 subnational regions (see Figure A.1). Intermediate demand in each sector, which was excluded from the simple model, is now determined by fixed technology coefficients (i.e., Leontief). Based on the Household Budget Survey (HBS) 2000-2001 (NBS 2002), labor markets are further segmented across four skill groups: (1) illiterate or uneducated workers, (2) workers with primary education, (3) workers with some secondary schooling, and (4) workers with secondary or higher schooling. Agricultural land and livestock capital in each region is further divided across small-scale and large-scale farms based on the 2002-2003 Agricultural Sample Survey (MINAG 2004). All factors are assumed to be fully employed, and capital is immobile across sectors. New capital from past investment is allocated to regions and sectors according to profit rate differentials under a "putty-clay" specification.

Figure A.1. Regions and zones in the Tanzania DCGE model

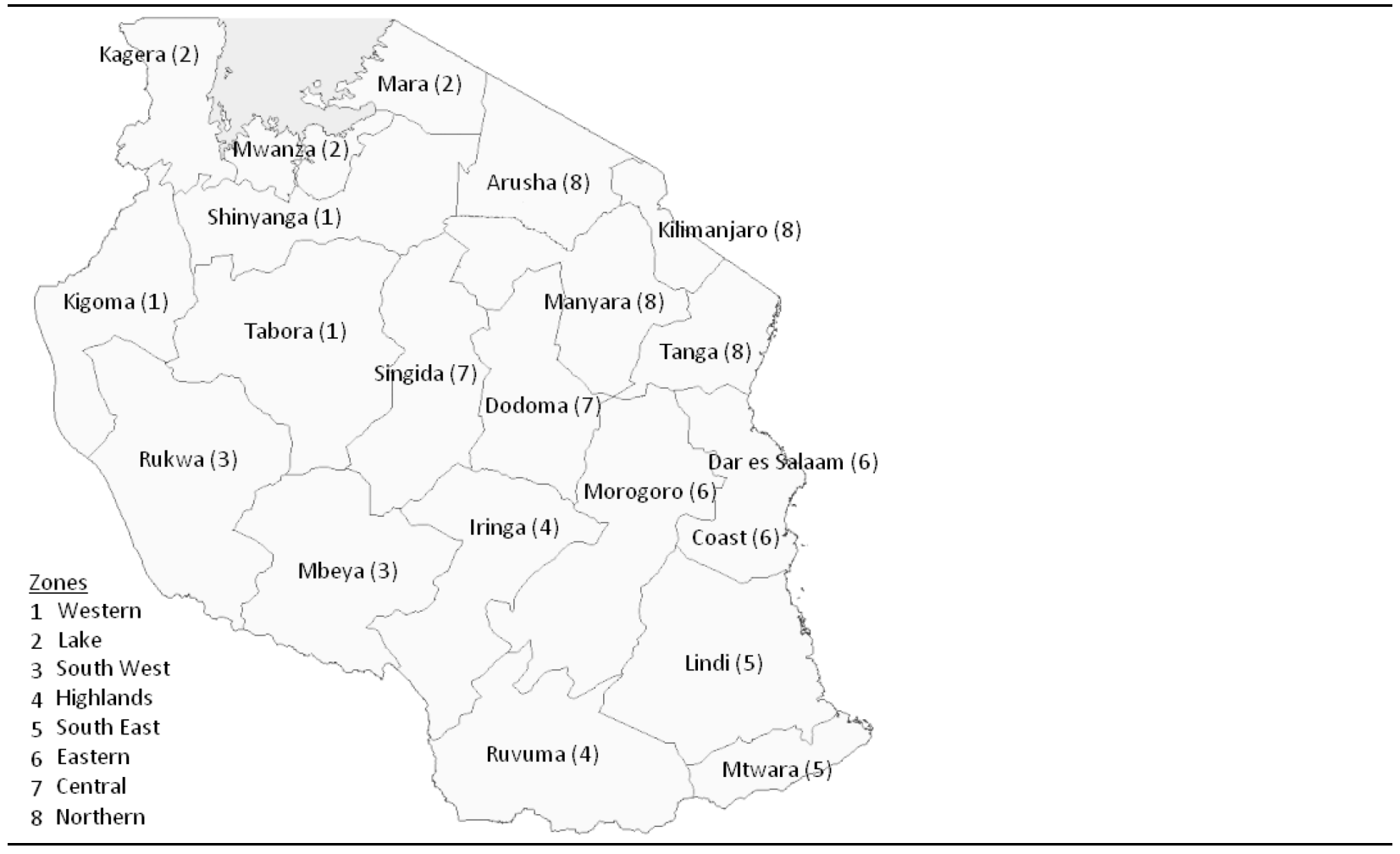


Table A.2. Sectors and regions in the Tanzania DCGE model

\begin{tabular}{ll}
\hline Sector and zone grouping & Detailed sectors or administrative regions \\
\hline Agriculture & Maize, sorghum, millet, rice, wheat and barley, cassava, other roots, pulses, \\
& coconuts, oilseeds, plantains, fruits, vegetables, coffee, cashew nuts, cotton, sisal, \\
& sugarcane, tea, tobacco, other cash crops, cattle, poultry, other livestock, fisheries, \\
& forestry \\
& Meat and fish processing, maize milling, rice milling, other milling, other food \\
processing, sugar refining, tobacco processing, beverages, textiles and clothing, & wood and paper products \\
& Mining, basic chemicals, fertilizer, petroleum products, rubber and plastics, \\
Other industry & nonmetallic minerals, metal products, machinery and equipment, other \\
& manufacturing, electricity and gas, water supply, construction \\
Services & Trade services, hotels and catering, transportation, communications, financial \\
& services, business and real estate, public administration, education, health, other \\
& services \\
Western & Kigoma, Shinyanga, Tabora \\
Lake & Kagera, Mara, Mwanza \\
South West & Mbeya, Rukwa \\
Highlands & Iringa, Ruvuma \\
South East & Lindi, Mtwara \\
Eastern & Coast, Dar es Salaam, Morogoro \\
Central & Dodoma, Singida \\
Northern & Arusha, Kilimanjaro, Manyara, Tanga \\
&
\end{tabular}

The full model still assumes national product markets. However, international trade is captured by allowing production and consumption to shift imperfectly between domestic and foreign markets, depending on the relative prices of imports, exports, and domestic goods. Initial trade patterns are taken from FAO (2009) and MOFEA (2008). Since Tanzania's economy is small, world prices are assumed to be fixed, and the current account balance is maintained by a flexible real exchange rate (i.e., the price index of tradable-to-nontradable goods). Production and trade elasticities are from Dimaranan (2006).

Households maximize a Stone-Geary utility function so that a linear expenditure system determines consumption with nonunitary income elasticities. Income elasticities were econometrically estimated using the HBS 2000-2001. Households are disaggregated across rural/urban and farm/nonfarm groups and by per capita expenditure quintiles. Farm households are further split across the 20 subnational regions. Table A.3 provides a broad summary of the demographic and production structure of the model. There are a total of 110 household groupings in the full DCGE model. These household groups pay taxes to the government based on fixed direct and indirect tax rates. Tax revenues finance exogenous recurrent spending, resulting in an endogenous fiscal deficit. In summary, the full Tanzania DCGE model captures the detailed sector and labor market structure of Tanzania's economy and the linkages between production, employment, and household incomes. 
Table A.3. Land and population distribution across regions and farm households

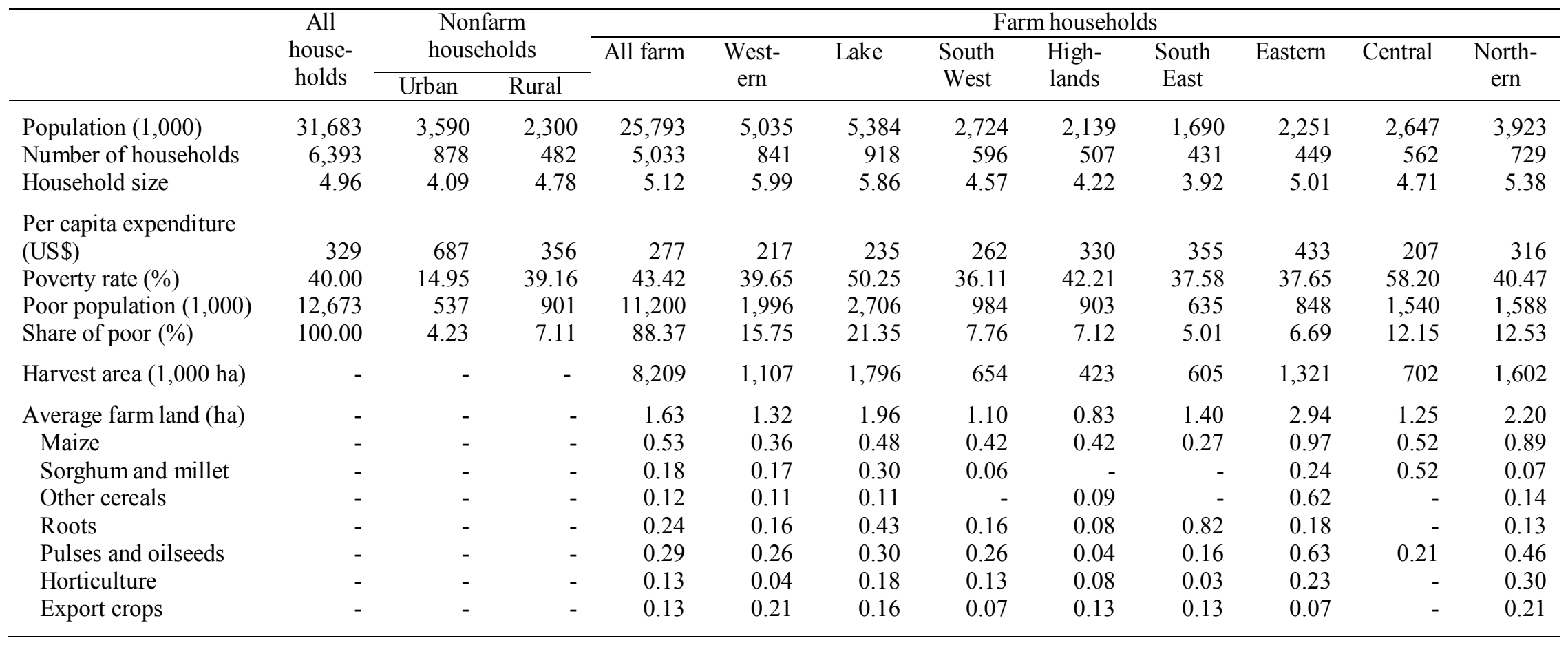

Source: Authors' calculations using Tanzania DCGE and microsimulation model, which is based on MINAG (2004, 2006) and HBS 2000-2001 (NBS 2002).

Note: Population data is from HBS 2000-2001 (NBS 2002). Per capita expenditure is based on consumption spending from the 2007 SAM. The poverty line identifies the bottom two per capita expenditure quintiles as poor. 


\section{APPENDIX B: MEASURING POVERTY AND NUTRITION OUTCOMES}

The DCGE model endogenously estimates the impact of sector growth patterns on household incomes and consumption patterns. There are 110 representative household groups in the model, disaggregated across 20 regions; five income quintiles; and rural/urban, farm/nonfarm groups. Each of the approximately 22,000 households questioned in HBS 2000-2001 (NBS 2002) are linked top-down to their corresponding representative household in the DCGE model. This permits an evaluation of changes in poverty and nutrition (i.e., caloric availability) at the household level. While this approach to microlevel modeling assumes constant within-group income distributions, it permits a more nuanced interpretation of income/nutrition changes within household groups relative to some predefined poverty or calorie line.

\section{Poverty Module}

The poverty module applies percentage changes in representative households' real consumption levels of each expenditure item to the corresponding individual households in the survey. Thus, for each simulation, a new household-specific level of per capita expenditure is estimated, which then serves as a welfare measure in standard poverty analysis. Thus, for each simulation, changes in poverty measures are calculated on the assumption that gains in per capita expenditures are shared equally among the household members. For our analysis we assume a per capita poverty line equal to the 40th percentile of the per capita expenditure (approximately TSh 6,736 per month in 2000 prices).

\section{Nutrition Module}

The nutrition module operates in a manner similar to the poverty module in that consumption changes in the DCGE model are linked top-down to micromodel household data. The nutrition module, however, only considers changes in the consumption quantities of food products. This in turn permits an evaluation of the change in caloric availability at the household level. Caloric availability is compared with a measure of the daily energy requirement of each household (a "calorie line") based on its size and demographic structure (i.e., age and gender composition). Households below this requirement are deemed "calorie deficient." The nutrition module allows us to determine which households move above the calorie line in each model simulation.

Adding a nutrition module to the microsimulation component of the DCGE model requires additional sets of information. The first is a detailed account of food consumption quantities measured in standard units (i.e., $100 \mathrm{~g}$ or $100 \mathrm{ml}$ ). This is available in HBS 2000-2001, where households reported both food quantities and the values of these food items. The second set of information is the calorie content of different food items. Detailed, Tanzania-specific information is drawn from Lukmanji et al. (2008). A third requirement is to define adult equivalence scales to account for the different numbers of calories per day that men, women, and children require. Equivalence scales were drawn from the United Nations University (UNU), World Health Organization (WHO), and Food and Agriculture Organization of the United Nations (FAO) (UNU, WHO, and FAO, 2004) (see Table B.1).

Table B.1. Caloric equivalence scales (measured relative to adult males, aged 19 to 59)

\begin{tabular}{lcccccccccc}
\hline & \multicolumn{10}{c}{ Age group } \\
\cline { 2 - 11 } & $0-2$ & $3-4$ & $5-6$ & $7-8$ & $9-10$ & $11-12$ & $13-14$ & $15-18$ & $19-59$ & $60+$ \\
\hline Male & 0.32 & 0.47 & 0.56 & 0.55 & 0.64 & 0.76 & 0.90 & 1.09 & 1.00 & 0.82 \\
Female & 0.29 & 0.44 & 0.51 & 0.65 & 0.75 & 0.89 & 1.05 & 1.28 & 1.20 & 0.98 \\
\hline
\end{tabular}

Source: Derived from UNU, WHO, and FAO (2004), as reported in Smith and Subandoro (2007). 
Together, this information was used to calculate the total calories available to each household in the survey. This can then be compared with calorie lines of 2,200 or 2,550 kilocalories per adult equivalent per day. These represent the minimum energy requirement for basal metabolic function and light office work, respectively. The calorie line of 2,200 kilocalories is consistent with NBS (2002) and the official food poverty line, and 2,550 kilocalories is consistent with the calorie line used in the World Bank (2009) study.

\section{Limitations and Data Cleaning}

Using household expenditure survey data to estimate caloric availability has certain limitation. First, these surveys are not typically designed to capture information on calorie consumption. Incorrect reporting may, among other things, relate to incorrect valuation of goods consumed, incorrect estimation of weight or volume measurements, and purchased foods not necessarily being consumed by household members themselves (see Smith and Subandoro 2007), hence the reference to caloric availability as opposed to caloric intake.

Consequently it is necessary to check for data inconsistencies and identify outliers that skew estimates of average caloric availability. One significant indication of outliers is a large deviation in the implicit price per calorie faced by a particular household for a specific commodity from the median or average price. Such price outliers may be indicative of an incorrect monetary valuation of foods purchased or an incorrect estimate of the weight or volume of such goods. Households may also simply over- or underreport the amount of food purchased for actual consumption by household members, and consequently caloric availability is lower or higher than expected given a household's income level. A further area of misreporting is when farming households incorrectly report expenditures on seeds as food expenditure.

We correct the caloric availability data in three ways. First, in households where the reported commodity-specific price per calorie is 50 percent or more above comparative median price in the region (Dar es Salaam, other urban areas, and rural areas are grouped for this purpose), the price per calorie is capped and calories available from a given level of expenditure are recalculated. Secondly, we assume that a household cannot obtain more than its daily needs from a single commodity (e.g., if daily calories from milled maize exceed 2,200 kilocalories, then these are capped at 2,200 kilocalories). Finally, we impute a new caloric availability level for households that are classified as calorie deficient yet report expenditure levels of more than $1-1 / 2$ times the official region-specific food poverty line. We also impute caloric availability values for households reportedly consuming more than three times the daily caloric requirement of 2,200 kilocalories per adult equivalent per day. ${ }^{12}$ Where imputed values once again exceed 6,600 kilocalories per day, the calories are capped at three times the daily limit. ${ }^{13}$

\footnotetext{
${ }^{12}$ A simple ordinary least squares imputation model is set up. Independent variables included are adult equivalent per capita expenditure, the share of the household budget spent on food, regional dummies (to account for regional food price differences), a farming household dummy variable, and a dummy for female-headed households.

${ }^{13}$ Endurance athletes typically require about 6,000 kilocalories per day; hence, 6,600 kilocalories is truly an upper bound.
} 


\section{APPENDIX C: COMPARING ALTERNATIVE POVERTY-GROWTH ELASTICITIES IN TANZANIA}

Poverty-growth elasticities (PGE) show the percentage decline in poverty from a 1 percent increase in per capita GDP. A key component of GDP is private consumption, which is estimated in national accounts and captured by household expenditure surveys (e.g., HBS 2000-2001). National accounts estimate private consumption differently from household surveys (see Ravallion 2001). Consumption is larger in national accounts because it includes a wider range of products, but surveys are less likely to sample households at the top of the income distribution. However, discrepancies may arise from estimation errors because national accounts treats private consumption as a residual between GDP at factor cost and other components of GDP at market prices. Over time, discrepancies may widen, and so household surveys can provide a check on consumption trends in national accounts.

Table C.1 shows alternative estimates of PGEs for Tanzania. According to national accounts, per capita GDP grew at 1.06 percent per year during 1992-2001, while the household survey estimated an annual decline in poverty of 0.86 percent (not percentage points). This gives a PGE of 0.82 (i.e., $0.86 / 1.06$ ). However, per capita consumption growth was higher in the surveys (i.e., 1.71 compared with 1.15 percent). If the surveys are more accurate than the national accounts and we assume similar deviations in other components of GDP at market prices, then per capita GDP would have grown faster during 1992-2001, at 1.53 percent per year. This gives a lower PGE of 0.57 (i.e., 0.86/1.53). In other words, if the surveys were more accurate at measuring growth than the national accounts were, then growth was less effective at reducing poverty during than the 1990s than national accounts suggest. The actual PGE may well lie somewhere between these two alternative estimates.

The situation is reversed during the 2000s. National accounts estimate that per capita GDP grew at 3.99 percent per year, which is well above our estimate of 1.32 percent per year from the household surveys. The household surveys estimate that poverty declined by 1.01 percent per year during 20012007. This means that the PGE varies from a low 0.25 based on national accounts to 0.76 based on survey estimates of GDP growth. The difference arises because either national accounts overestimate or the household surveys underestimate GDP growth. Understanding these differences is important because they imply different trends in the effectiveness of economic growth to reduce poverty. Estimates of PGEs based on national accounts suggest a deterioration of the growth-poverty relationship from the 1990s to the 2000 s, whereas the household surveys suggest the opposite.

Table C.1. Alternative estimates of poverty-growth elasticities

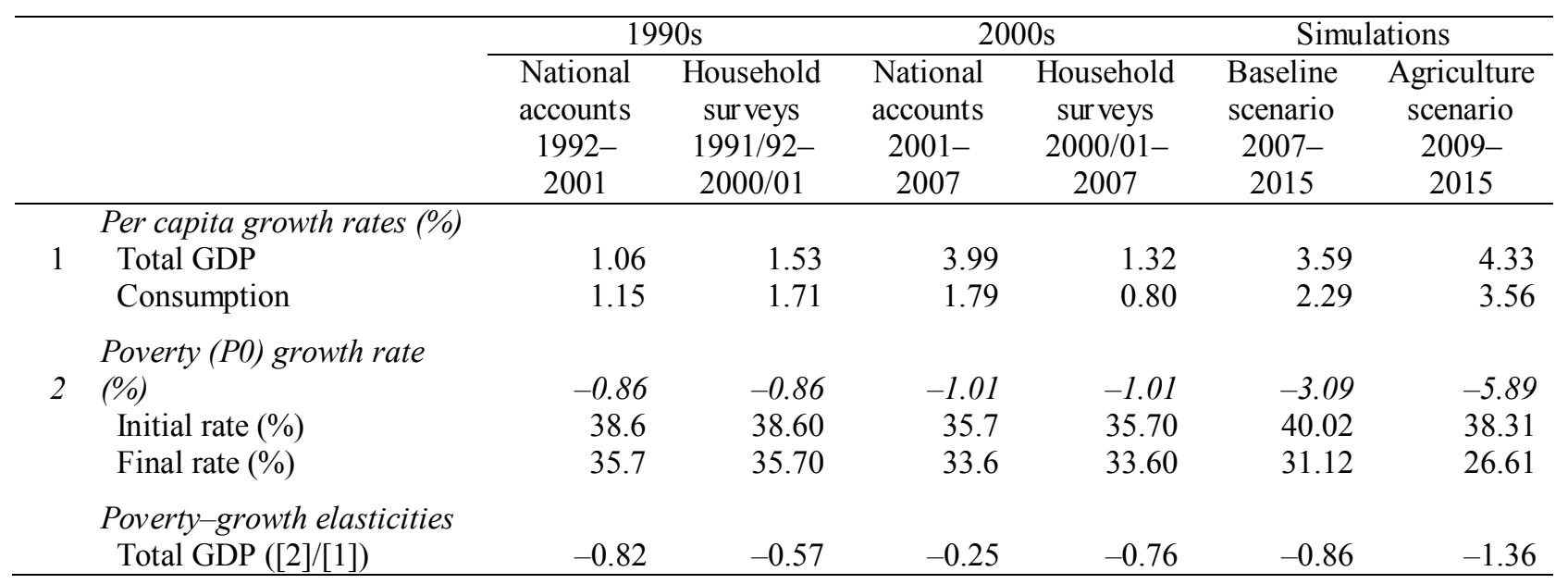

Source: Authors' calculations using MOFEA (2008), World Bank (2008 and 2009), and results from the Tanzania DCGE and microsimulation model. 
Note: Total per capita GDP growth rates for the household surveys (columns 2 and 4) are estimated assuming the same deviations for all expenditure components of GDP at market prices as reported for private consumption.

In our analysis we simulate the detailed sector growth rates reported in official agricultural production data. Our results indicate that agriculture's GDP growth rate in national accounts is broadly consistent with production trends at the crop and subsector levels (i.e., our estimated agricultural GDP growth rate for 2007-2015 in the baseline scenario is similar to the one reported in national accounts for 1998-2007 to which the baseline scenario is calibrated). Thus, if agricultural GDP growth is indicative of other sectors' performance and if the economy has not had very large structural changes during 19982007, then our model results suggest that economic growth was not as low as the household surveys report. Conversely, our baseline scenario produces PGEs similar to those estimated using the household surveys. If this result is accurate, then it suggests that the distribution of growth during 2001-2007 may have been appropriately captured by the surveys.

Together, these conclusions suggest that the discrepancies between national accounts and the surveys during 2001-2007 may have arisen from (1) the national accounts' overestimation of nonagricultural growth, (2) the surveys' underestimation of consumption growth and poverty reduction, or (3) both. Any of these explanations is plausible given the long time period since Tanzania last rebased its national accounts, as well as the extremely large price increases reported in the surveys (see World Bank 2009). However, regardless of which source is most accurate, Tanzania's PGE is well below Uganda's (i.e., 1.4 during 1993-2006), which has a similar per capita GDP and national poverty headcount rate (Thurlow, forthcoming). 


\section{REFERENCES}

Abdulai, A., and D. Aubert. 2004. Nonparametric and parametric analysis of calorie consumption in Tanzania. Food Policy 29: 113-129.

Alderman, H., H. Hoogeveen, and M. Rossi. 2006. Reducing child malnutrition in Tanzania. Combined effects of income growth and program intervention. Economics and Human Biology 4: 1-23.

Dimaranan, B. ed. 2006. Global trade, assistance, and production: The GTAP 6 data base. Center for Global Trade Analysis, Purdue University, Ind., U.S.A.

Ecker, O., and M. Qaim. 2009. Analyzing the nutritional impacts of policies: An empirical study for Malawi. Unpublished Ph.D. dissertation. University of Honnheim, Germany.

Fan, S., D. Nyanga and N. Rao. 2005. Public investment and poverty reduction in Tanzania. Development Strategies and Governance Discussion Paper 18, International Food Policy Research Institute, Washington D.C.

FAO. 2009. FAOSTAT database, Food and Agriculture Organization of the United Nations, Rome. $<$ faostat.fao.org $>$ Accessed August 2009.

Hoddinott, J., E. Skoufias, and R. Washburn. 2000. The impact of PROGRESA on consumption: Report submitted to PROGRESA. Washington, D.C.: International Food Policy Research Institute.

Kilima, F.T.M., C. Chung, P. Kenkel, and E. R. Mbiha. 2008. Impact of market reform on spatial volatility of maize prices in Tanzania. Journal of Agricultural Economics 59 (2): 257-270.

Lukmanji, Z., E. Hertzmark, N. Mlingi, V. Assey, G. Ndossi, and W. Fawzi. 2008. Tanzania food composition tables. First Edition. Muhimbili University of Health and Allied Sciences, Dar es Salaam, Tanzania; Tanzania Food and Nutrition Centre, Dar es Salaam, Tanzania; and Harvard School of Public Health, Boston, U.S.A.

MINAG. 2004. National sample census of agriculture, 2002/2003. Ministry of Agriculture, Food Security and Cooperatives, Dar es Salaam, Tanzania.

.2006. Agriculture basic data 1998/99-2004/05. Ministry of Agriculture, Food Security and Cooperatives, Dar es Salaam, Tanzania.

MOFEA. 2008. The economic survey 2007. Ministry of Finance and Economic Affairs, Dar es Salaam, Tanzania.

NBS (National Bureau of Statistics). 2002. Household budget survey 2000/01. National Bureau of Statistics, Dar es Salaam, Tanzania.

Nkonya, E., T. Schroeder, and D. Norman. 1997. Factors affecting adoption of improved maize seed and fertilizer in northern Tanzania. Journal of Agricultural Economics 48 (1): 1-12.

Ravallion, M. 2001. Measuring aggregate welfare in developing countries: How well do national accounts and survey agree? Policy Research Working Paper 2665. Washington D.C.: World Bank.

Smith, L., and A. Subandoro. 2007. Measuring food security using household expenditure surveys. Food Security in Practice Technical Guide Series. Washington, D.C.: International Food Policy Research Institute.

Strauss, J., and D. Thomas. 1995. Human resources: Empirical modeling of household and family decisions. In Handbook of Development Economics, Vol. 3A, ed. J. Behrman and T. N. Srinivasan. Amsterdam: North-Holland.

Subramanian, S., and A. Deaton. 1996. The demand for food and calories. Journal of Political Economy 104 (1): $133-162$.

Thurlow, J. Forthcoming. Prospects for accelerating agricultural growth and reducing poverty in Uganda. Forthcoming in In pursuit of prosperity in rural Uganda-Opportunities and constraints, ed. S. Benin and T. Benson. Washington, D.C.: International Food Policy Research Institute.

Thurlow, J., and P. Wobst. 2003. Poverty-focused social accounting matrices for Tanzania. Trade and Macroeconomics Discussion Paper 112. Washington, D.C.: International Food Policy Research Institute. 
UNU, WHO, and FAO (United Nations University, World Health Organization, and Food and Agriculture Organization of the United Nations). 2004. Human energy requirements: Report of a joint FAO/WHO/UNU expert consultation, Rome, October 17-24, 2001. FAO Food and Nutrition Technical Report Series 1. Rome: FAO.

World Bank. 2007. Advancing nutrition for long-term, equitable growth. Report 41315-TZ. Washington, D.C.: World Bank.

. 2008. World development indicators 2008. <www.worldbank.org> Accessed August 2009.

.2009. Lost in transition: Income poverty reduction since 2001. Unpublished paper prepared for the Research and Analysis Working Group. February 2009. 



\section{RECENT IFPRI DISCUSSION PAPERS}

\section{For earlier discussion papers, please go to www.ifpri.org/pubs/pubs.htm\#dp. All discussion papers can be downloaded free of charge.}

946. Labeling genetically modified food in India: Economic consequences in four marketing channels. Sangeeta Bansal and Guillaume Gruère, 2010.

945. Toward a typology of food security in developing countries. Bingxin Yu, Liangzhi You, and Shenggen Fan, 2010.

944. Paving the way for development? The impact of transport infrastructure on agricultural production and poverty reduction in the Democratic Republic of Congo. John Ulimwengu, Jose Funes, Derek Headey, and Liangzhi You, 2009.

943. Formal-informal economy linkages and unemployment in South Africa. Rob Davies and James Thurlow, 2009.

942. Recent food prices movements: A time series analysis. Bryce Cooke and Miguel Robles, 2009.

941. Decentralization, agricultural services and determinants of input use in Nigeria. Kamiljon T. Akramov, 2009.

940. How important are peer effects in group lending? Estimating a static game of incomplete information. Shanjun Li, Yanyan Liu, and Klaus Deininger, 2009.

939. Rice production responses in Cambodia. Bingxin Yu and Shenggen Fan, 2009.

938. A latent class approach to investigating consumer demand for genetically modified staple food in a developing country: The case of gm bananas in Uganda. Enoch Kikulwe, Ekin Birol, Justus Wesseler, and José Falck-Zepeda, 2009.

937. Cluster-based industrialization in China: Financing and performance. Cheryl Long and Xiaobo Zhang, 2009.

936. Sensitivity of welfare effects estimated by equilibrium displacement model: A biological productivity growth for semisubsistence crops in Sub-Sahara African market with high transaction costs. Hiroyuki Takeshima, 2009.

935. Assessing household vulnerability to climate change: The case of farmers in the Nile Basin of Ethiopia. Temesgen T. Deressa, Rashid M. Hassan, and Claudia Ringler, 2009.

934. Do external grants to district governments discourage own-revenue generation?: A look at local public finance dynamics in Ghana. Tewodaj Mogues, Samuel Benin, and Godsway Cudjoe, 2009.

933. Impacts of prenatal and environmental factors on child growth: Evidence from Indonesia. Futoshi Yamauchi, Katsuhiko Higuchi, and Rita Nur Suhaeti, 2009.

932. Rich consumers and poor producers: Quality and rent distribution in global value chains. Johan F.M. Swinnen and Anneleen Vandeplas, 2009.

931. Economic growth and distribution of income: A Growth model to fit Ghanaian data. Harumi T. Nelson, Terry L. Roe, and Xinshen Diao, 2009.

930. Trade liberalization, poverty, and food security in India. Manoj Panda and A. Ganesh-Kumar, 2009.

929. Improving the proof: Evolution of and emerging trends in impact assessment methods and approaches in agricultural development. Mywish K. Maredia, 2009.

928. Improving diet quality and micronutrient nutrition: Homestead food production in Bangladesh. Lora Iannotti, Kenda Cunningham, and Marie Ruel, 2009.

927. Land-tenure policy reforms: Decollectivization and the Doi Moi System in Vietnam. Michael Kirk and Tuan Nguyen, 2009.

926. “Crossing the river while feeling the rocks:" Incremental land reform and its impact on rural welfare in China. John W. Bruce and Zongmin Li, 2009.

925. Rich food for poor people: Genetically improved tilapia in the Philippines. Sivan Yosef, 2009.

924 .Rural and urban linkages: Operation Flood's role in India's dairy development. Kenda Cunningham, 2009.

923. The global effort to eradicate rinderpest. Peter Roeder and Karl Rich, 2009.

922. The mungbean transformation: Diversifying crops, defeating malnutrition. Subramanyan Shanmugasundaram, J. D. H. Keatinge, and Jacqueline d'Arros Hughes, 2009. 


\section{INTERNATIONAL FOOD POLICY RESEARCH INSTITUTE}

\section{www.ifpri.org}

IFPRI HEADQUARTERS

2033 K Street, NW

Washington, DC 20006-1002 USA

Tel.: +1-202-862-5600

Fax: +1-202-467-4439

Email: ifpri@cgiar.org

IFPRI ADDIS ABABA

P. O. Box 5689

Addis Ababa, Ethiopia

Tel.: +251116463215

Fax: +251116462927

Email: ifpri-addisababa@cgiar.org

IFPRI NEW DELHI

CG Block, NASC Complex, PUSA

New Delhi 110-012 India

Tel.: 9111 2584-6565

Fax: 9111 2584-8008 / 2584-6572

Email: ifpri-newdelhi@cgiar.org 